\title{
Pesquisa e Caracterização de Amostras de ExPEC ("Extraintestinal Pathogenic Escherichia coli") Isoladas de Infecções do Trato Urinário (ITU) de Cães e Gatos
}

Dissertação apresentada ao Programa de PósGraduação em Microbiologia do Instituto de Ciências Biomédicas da Universidade de São Paulo, para obtenção do Título de Mestre em Ciências Biológicas. 


\section{LIKA OSUGUI}

\section{Pesquisa e Caracterização de Amostras de ExPEC ("Extraintestinal Pathogenic Escherichia coli") Isoladas de Infecções do Trato Urinário (ITU) de Cães e Gatos}

Dissertação apresentada ao Programa de Pós-Graduação em Microbiologia do Instituto de Ciências Biomédicas da Universidade de São Paulo, para obtenção do Título de Mestre em Ciências Biológicas.

Área de Concentração: Microbiologia

Orientador: Prof. Dr. Antonio Fernando Pestana de Castro 
DADOS DE CATALOGAÇÃO NA PUBLICAÇÃO (CIP)

Serviço de Biblioteca e Informação Biomédica do

Instituto de Ciências Biomédicas da Universidade de São Paulo

(C) reprodução total

\section{Osugui, Lika.}

Pesquisa e caracterização de Amostras de ExPEC ("Extraintestinal Pathogenic Escherichia coli") isoladas de infecções do trato urinário (ITU) de Cães e Gatos / Lika Osugui. -- São Paulo, 2008.

Orientador: Antonio Fernando Pestana de Castro.

Dissertação (Mestrado) - Universidade de São Paulo. Instituto de Ciências Biomédicas. Departamento de Microbiologia. Área de concentração: Microbiologia. Linha de pesquisa: Estudo dos fatores de virulência envolvidos nas doenças ocasionadas por Escherichia coli.

Versão do título para o inglês: Characterization of ExPEC ("Extraintestinal Pathogenic Escherichia coli") isolated from dogs and cats with uinary tract infections (UTI).

Descritores: 1. Infecções do trato urinário (ITU) 2. Cães e gatos 3. ExPEC (Extraintestinal Pathogenic Escherichia coli 4. UPEC

("Uropathogenic Escherichia coli") 5. Fatores de virulência 6. Grupos filogenéticos de Escherichia coli I. Castro, Antonio Fernando Pestana de II. Universidade de São Paulo. Instituto de Ciências Biomédicas. Programa de Pós graduação em Microbiologia III. Título. 
Candidato(a):

Título da Dissertação:

Orientador(a):
Lika Osugui.

Pesquisa e caracterização de Amostras de ExPEC ("Extraintestinal Pathogenic Escherichia coli") isoladas de infecções do trato urinário (ITU) de Cães e Gatos.

Antonio Fernando Pestana de Castro.

A Comissão Julgadora dos trabalhos de Defesa da Dissertação de Mestrado, em sessão pública realizada a ..................................,
( ) Aprovado(a)
( ) Reprovado(a)

Examinador(a): Assinatura:

Nome:

Instituição:

Examinador(a): Assinatura:

Nome:

Instituição:

Presidente: Assinatura:

Nome:

Instituição: 


\section{Certificado da Comissäo de Etica em Experimentasāoo Animal}

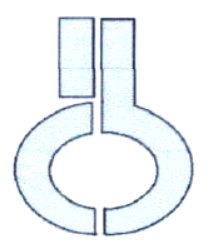

UNIVERSIDADE DE SÃO PAULO INSTITUTO DE CIÊNCIAS BIOMÉDICAS

Cidade Universitária "Armando de Salles Oliveira"

Av. Prof. Lineu Prestes, 2415 - CEP. 05508-000 Săo Paulo, SP - Brasil

Telefone :(55) (011) 3091.7733 - telefax : (55) (011) 3091.7438

e-mail: cep@icb.usp.br

\section{Certificado}

Certificamos que o protocolo registrado sob $\mathrm{n}^{\circ} \mathbf{1 2 8}$ nas fls. $\mathbf{3 8}$ do livro $\mathbf{2}$ para uso de animais em experimentação, sob a responsabilidade de Antônio Fernando Pestana de Castro, Coordenador(a) da Linha de pesquisa "Pesquisa $\boldsymbol{e}$ caracterização de Escherichia coli Uropatogênicas (UPEC) em infecções do trato urinário (ITU) de cães e gatos" do qual participou(aram) o(s) alunos Lika Osugui e a pesquisadora Vânia Maria de Carvalho, está de acordo com os Princípios Éticos de Experimentação Animal adotado pelo Colégio Brasileiro de Experimentação Animal (COBEA) e foi aprovado pela COMISSÃO DE ÉTICA EM EXPERIMENTAÇÃO ANIMAL (CEEA) em 06.10.2006.

São Paulo, 09 de outubro de 2006.
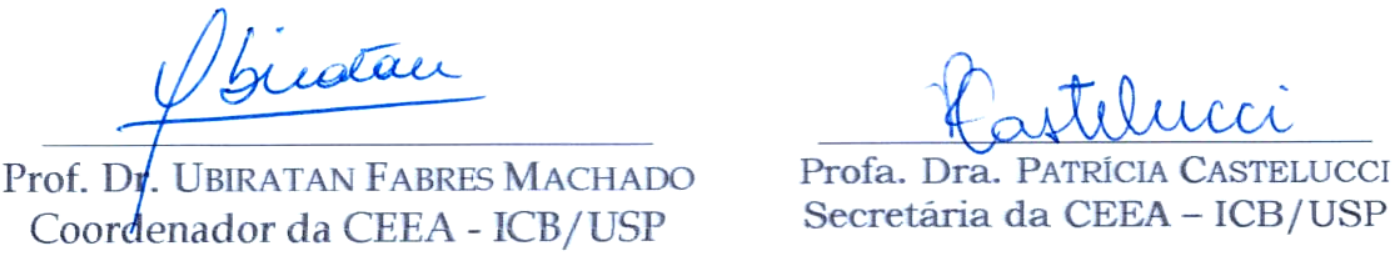
Aos meas pais, por estarem presentes desde os meas primeiros tracados, que se transformaram nestas linhas e ao Samir por todo o amor e apoio, sempre! 


\section{Agradecimentos}

Ao Professor Pestana pela orientação e por tudo o que proporcionou à minha formação.

À minha querida amiga e co-orientadora Vania, pelos ensinamentos, pela paciência e por ser uma constante fonte de inspiração.

Ao Dr. Shingo Yamamoto, da Universidade de Kyoto, pelo envio de amostras-padrão de UPEC.

Ao Dr. James R. Johnson, do Veterans Affairs Medical Center e da Universidade de Minnesota, pelo envio das amostras-padrão de ExPEC e dos protocolos para realização da PCR Multiplex.

À Dra. Rosa Maria Silva, da UNIFESP, pelo envio da amostra-padrão de E. coli do grupo B1.

À Dra. Maria Christina Christovão Ramos e equipe do Lab\&Vet, pelo envio das amostras de animais utilizadas neste trabalho.

À Dra Kinue Irino, do Instituto Adolfo Lutz, pela sorotipagem das amostras.

À Adriana e Leila, tutoras dos meus primeiros passos na vida científica, que contribuíram para a minha formação e, acima de tudo, pela amizade, que proporcionou tantos momentos felizes.

À Cláudia, Dani, Eliana, Luciana e Ylanna, amigas para todas as horas, por tudo o que fizeram e ainda fazem por mim.

Às meninas da secretaria Alice, Zelma, Aninha e Naíde que me acompanham e auxiliam desde o meu ingresso no departamento.

Às técnicas do Laboratório de Biologia Molecular e Celular da Unip, Cleide e Suzana, pelo companheirismo e por toda a ajuda.

Ao Conselho Nacional de Apoio à Pesquisa (CNPq) e à Fundação de Amparo à Pesquisa do Estado de São Paulo (FAPESP) pelo auxílio financeiro ao projeto.

E a todos que de alguma forma contribuíram, minha gratidão 
"Eo mea coraçāo é um albergue aberto toda a noite. Tenho pela vida um interesse ávido Que busca compreendê-la sentindo-a muito." 


\section{Resumo}

OSUGUI L. Pesquisa e Caracterização de Amostras de ExPEC (" Extraintestinal Pathogenic Escherichia coli ") Isoladas de Infecções do Trato Urinário (ITU) de Cães e Gatos. 200876 f. Dissertação (Mestrado em Microbiologia) - Instituto de Ciências Biomédicas, Universidade de São Paulo, São Paulo, 2008.

As infecções causadas por cepas de ExPEC ("Extraintestinal Pathogenic Escherichia coli”) incluem meningite neonatal, pneumonia, bacteremia, além das infecções do trato urinário (ITU), sendo estas últimas as mais freqüentes. Entre os fatores de virulência (FV) presentes nestas cepas encontram-se adesinas, toxinas, sideróforos, invasinas e evasinas, localizados em plasmídios ou ilhas de patogenecidade (PAI). O objetivo deste estudo foi a caracterização de 45 cepas de $E$. coli isoladas de 33 cães e 7 gatos com ITU, quanto aos FV, sorotipos e grupos filogenéticos. Entre os isolados, 64\% tiveram os sorogrupos determinados, dos quais relacionados foram encontrados os seguintes relacionados a infecções extra-intestinais: O6 (20\%), O2 (16\%), O25 (4\%), O4 e 011 (4\% cada um). Dos genes relacionados às adesinas, fimH apresentou-se em $100 \%$ das cepas, pap em 47\%, sfa em $33 \%$ e iha em 4\%; nenhuma amostra foi positiva para afal. Em 29\% das cepas identificou-se o gene ibeA. Dos marcadores para toxinas, cnf1 e hlyA apresentaram as freqüências de $31 \%$ e $27 \%$, respectivamente. Dentre os sideróforos, fyuA foi mais freqüente $(80 \%)$ que iucD (22\%), ocorrendo associação de ambos em $18 \%$ das cepas. $51 \%$ das cepas possuíam o gene traT. O plasmídio ColV (cvaC) foi encontrado em $20 \%$ das amostras e a seqüência relacionada a PAI I $\mathrm{CFT}_{\text {CF3 }}$ (malX) de UPEC foi identificada em $67 \%$ destas. Todos os isolados felinos foram agrupados em B2 (89\%) e D (11\%), enquanto que os caninos foram classificados nos grupos A $(5,5 \%)$, B1 $(19,5 \%)$, B2 $(55,5 \%)$ e D (19,5\%). Estes resultados sugerem que as ExPEC isoladas de cães e gatos apresentam potencial patogênico para ocasionar doenças mais graves que as ITU, à semelhança do que ocorre em humanos. Além disso, a similitude com as amostras de ExPEC humana reforça a hipótese acerca de seu potencial zoonótico.

Palavras-chave: Infecções do Trato Urinário (ITU). Cães e gatos. ExPEC (“Extraintestinal Pathogenic Escherichia coli”). UPEC ("Uropathogenic Escherichia coli"), Fatores de virulência. Grupos Filogenéticos de E. coli. 


\section{Abstract}

OSUGUI L. Characterization of ExPEC (" Extraintestinal Pathogenic Escherichia coli ") Isolated from Dogs and Cats with Urinary Tract Infections (UTI). 200878 f. Dissertação (Mestrado em Microbiologia) - Instituto de Ciências Biomédicas, Universidade de São Paulo, São Paulo, 2008.

The ability of ExPEC to cause extraintestinal infections in humans, dogs, and cats is associated with the expression of a variety of virulence factors (VF), including adhesins, invasins, toxins, siderophores, and evasins, located at plasmids or pathogenicity islands (PAI). The aim of this study was to evaluate the frequency of VF related to ExPEC, serotypes, and phylogenetic groups in 45 strains isolated from 33 dogs and 7 cats with UTI. $64 \%$ of the isolates presented serogroups related with extraintestinal infections, e.g. O6 (20\%), O2 (16\%), O25 (4\%), O4 e 011 (4\% each one). Among adhesins coding genes, fimH was found in all strains, 21 isolates (47\%) were positive for pap, 15 (33\%) for sfa, and 2 for iha (4\%). None of the 45 strains presented afal. The yersiniabactin siderophore was more frequent (36 strains) than aerobactin (10 strains). These two genes were found together in $18 \%$ of the strains. The frequency of the toxin genes was $31 \%$ for cnf1 and $27 \%$ for $h l y A$. $20 \%$ of the strains presented cvaC gene, a ColV plasmid marker, $51 \%$ the traT gene and $29 \%$ the ibeA gene. The PAI I IFT073 related sequence (malX) was found in $67 \%$ of the strains. All feline strains were concentrated in B2 (89\%) and D (11\%) phylogenetic groups, whereas the canine ones were distributed in the four groups, A $(5,5 \%), B 1$ $(19,5 \%)$, B2 (55,5\%) and D (19,5\%). These findings suggesting that ExPEC isolated from dog and cat contain virulence markers that may cause diseases, more severe than UTI, likewise in humans. Besides, these close similarity between human and animal ExPEC supports the hypotesis of zoonotic potencial of them.

Key words: Urinary Tract Infections (UTI). Dogs and Cats. ExPEC ("Extraintestinal Pathogenic Escherichia coli”). UPEC (“Uropathogenic Escherichia coli”). Virulence Factors. E. coli Phylogenetic Groups. 


\section{Lista de Tabelas}

Tabela 1. Interpretação da avaliação quantitativa das culturas bacterianas de urina de cães e gatos

Tabela 2. Amostras padrão utilizadas na caracterização de E. coli, segundo os testes em que foram empregadas, características de virulência, sorotipo e procedência

Tabela 3. Descrição dos genes pesquisados nas amostras de $E$. coli, seqüências, posição, tamanho dos amplificados e referências bibliográficas

Tabela 4. Descrição dos genes utilizados para classificação de grupos filogenéticos de $E$. coli, seqüência dos iniciadores e tamanho do fragmento 32 amplificado

Tabela 5. Caracterização dos animais amostrados, tipo de colheita da urina, resultados da urinálise e microrganismos isolados

Tabela 6. Amostras de Escherichia coli isoladas de gatos e cães com ITU, com determinação do grupamento filogenético, sorotipo e resultado da pesquisa de marcadores de FV pela PCR

Tabela 7. Amostras isoladas de gatos e cães com ITU, em relação ao grupamento filogenético, sorotipo, presença de FV que codificam a produção de adesinas e a expressão destas através do teste de hemaglutinação 
Sumário

1 lntrodusāo

2 Objetivo

3 Material e Métodos

3.1 Animais

3.2 Cultura e Identificação Bacteriana

3.3 Amostras-Padrão

3.4 Sorotipagem

3.5 Reação em Cadeia da Polimerase

3.5.1 Pesquisa de Fatores de Virulência

3.5.2 Determinação de Grupos Filogenéticos

3.6 Teste de Produção de Hemolisina

3.7 Teste de Hemaglutinação

4 Resaltados

5 Discussäa

6 Conclusōes

Referências Bibliográficas
12

23

24

24

24

26

26

28

28

32

34

34

36

53

63

65 


\section{Introdução}

As infecções do trato urinário (ITU) de origem bacteriana ocorrem devido a dois fatores concomitantes: a ruptura nos mecanismos de defesa do organismo hospedeiro e a presença de um número suficiente de microrganismos virulentos capaz de aderir, multiplicar e persistir em uma porção do trato urinário (BARTGES, 2004).

Estima-se que aproximadamente de 10 a $14 \%$ dos cães serão afetados durante sua vida por ITU ocasionadas por bactérias, com maior prevalência em fêmeas. Nos felinos, as ITU são menos freqüentes, afetando principalmente animais mais idosos, acima de 10 anos, relacionadas principalmente com indivíduos submetidos a procedimentos cirúrgicos (BARTGES, 2004; CETIN et al., 2003; GREENE, 2006; LEES, 1996; LULICH e OSBORNE, 2004; NORRIS et al., 2000).

As ITU geralmente iniciam-se na bexiga, mas podem evoluir para os rins, ou disseminar-se para o sangue. De acordo com o sítio da infecção podem ser classificadas como: bacteriúria, com a presença de bactérias na urina, na maioria dos casos, assintomática ("Asymptomatic Bacteriuria" - $A B U$ ); cistite, quando acomete o trato urinário inferior (bexiga e uretra) ou pielonefrite, quando a infecção propaga-se para o trato urinário superior, instalando-se nos rins e ureteres adjacentes (GREENE, 2006; POLZIN, 1994; ROOS et al., 2006).

A manifestação de sinais clínicos em cães e gatos pode ou não estar presente, variando de acordo com a predisposição do animal, o sítio e a duração da infecção, como também a quantidade de microrganismos e seus fatores de virulência. As cadelas com anormalidades vulvares, dermatites perivulvares e estenose vaginal podem apresentar um maior risco ao desenvolvimento das ITU, assim como gatos machos com uretrostomia no períneo. Polaciúria, estrangúria ou disúria, dor associada à palpação, turvação da urina e/ou hematúria, podem ser observadas em infecções do trato urinário inferior. Animais com infecção no trato urinário superior podem apresentar pirexia, letargia, anorexia, dor localizada em um 
ou ambos os rins, hematúria, septicemia ou falência renal. (BARTGES, 2004; POLZIN, 1994).

O trato urinário é usualmente um ambiente estéril, excetuando-se a uretra distal que apresenta, naturalmente, microrganismos residentes. A manutenção deste ambiente ocorre devido à presença de uma série de mecanismos que atuam na prevenção das ITU. As propriedades antibacterianas da urina, como a alta osmolaridade, baixo pH, presença de ácidos orgânicos e concentração de uréia, além do fluxo e produção constantes, os quais possibilitam a eliminação mecânica de microrganismos, são alguns destes. Devem ser consideradas ainda as barreiras de defesa das mucosas e a imunocompetência sistêmica do hospedeiro (BARSANTI, 1998; BARTGES, 2004; BLANCO e BARTGES, 2001; SEGUIN et al., 2003).

Os organismos constituintes da microbiota do intestino e do trato urogenital inferior estão entre os principais agentes das ITU, onde o desenvolvimento de tais infecções indica o desequilíbrio entre a relação do hospedeiro com sua microbiota (BUSH, 1976; POLZIN, 1994). Para que ocorra a infecção, a bactéria deve fixar-se e colonizar a mucosa do orifício uretral, com posterior ascensão pela uretra, até a bexiga. A pielonefrite é a conseqüência da ascensão da infecção aos rins (GREENE, 2006).

Dentre os vários microrganismos referidos na literatura como agentes etiológicos de ITU, as Gram positivas Staphylococcus spp., Streptococcus spp. e Enterococcus spp., são as encontradas com maior freqüência. Entretanto, as bactérias Gram negativas (Escherichia coli, Proteus spp., Klebsiella spp., Pseudomonas spp. e Enterobacter spp.) respondem por $75 \%$ dos casos de ITU (BARSANTI, 1998; SEGUIN et al., 2003).

Entre as Gram negativas, a Escherichia coli é considerada a bactéria mais comumente isolada, tanto de animais como do homem, possivelmente por sua "habilidade" em ultrapassar algumas das barreiras do sistema urinário (BARTGES, 2004; BLANCO e BARTGES, 2001; BOWER et al., 2005; JOHNSON et al., 2003; LING et al., 2001; LOW et al., 1988; SEGUIN et al., 2003). 
A E. coli é um bacilo fermentativo, pertencente à família Enterobacteriaceae, que cresce rapidamente em meios bacteriológicos simples, incluindo o ágar MacConkey, no qual forma colônias, na maioria das vezes, fermentadoras de lactose. Entre outras características que auxiliam sua identificação estão: a reação positiva para indol, testes negativos para a produção de urease e $\mathrm{H}_{2} \mathrm{~S}$ e a não utilização de citrato como única fonte de carbono. É o principal organismo anaeróbio facultativo presente no trato intestinal da maioria das espécies animais de sangue quente, na proporção de $10^{7}$ a $10^{9}$ microrganismos por grama de fezes. $O$ intestino estéril de animais recém-nascidos torna-se rapidamente colonizado, pelas bactérias, provenientes das mães e do próprio ambiente (GYLES e FAIRBROTHER, 2004).

As infecções do trato urinário, ocasionadas por E. coli uropatogênica ("Uropathogenic E. coll" - UPEC), encontram-se entre as mais freqüentes infecções extra-intestinais tanto em animais como no homem (BARTGES, 2004; DOWLING, 1996; JOHNSON et al., 2003; LULICH e OSBORNE, 2004). No entanto, os isolados de UPEC apresentam fatores de virulência $(F V)$ encontrados também em cepas de E. coli associada a sépsis ("Sepsis-Associated E. coll' - SEPEC) e E. coli associada a meningite neonatal ("Neonatal Meningitis-Associated E. coll" - NEMEC). Assim, Russo e Johnson (2000) sugeriram a substituição desses acrônimos pelo de ExPEC ("Extraintestinal Pathogenic E. coll'), uma designação mais inclusiva para cepas capazes de colonizar e ocasionar doenças nos mais diferentes sítios anatômicos.

A classificação tradicional de amostras de $E$. coli baseia-se na determinação de antígenos somáticos $(\mathrm{O})$, polissacarídeos capsulares $(K)$ e flagelares $(H)$, permitindo a diferenciação entre amostras patogênicas das comensais (GYLES e FAIRBROTHER, 2004; WILES et al., 2008).

O lipopolissacarídeo (LPS), também conhecido como endotoxina, é um componente essencial e característico da membrana externa das bactérias Gram negativas, responsável por diversos efeitos biológicos, incluindo a inflamação e a resistência ao soro. Constituí-se por três partes: lipídeo A, o componente tóxico, a região do cerne e o antígeno $O$, específico para cada um dos mais de 176 sorogrupos. A diversidade deste antígeno provém da ordem, composição e ligação entre os oligossacarídeos, compostos por resíduos de dois a seis açúcares (unidades O), repetidos de 10 a 30 vezes (MÜHLDORFER e HACKER, 1994; 
REEVES et al., 1996; SAMUEL e REEVES, 2003; STENUTZ et al., 2006; WHITFIELD, 1995).

$\mathrm{Na}$ década de 1940, Kauffmann utilizou as mesmas técnicas sorológicas empregadas para tipagem de salmonelas em cepas de E. coli estabelecendo o primeiro esquema de tipagem desta bactéria. Já nesta época observou-se a freqüência de determinados sorogrupos nas infecções extra-intestinais (ORSKOV e ORSKOV, 1985).

Dentre os sorogrupos relatados por diversos pesquisadores como os mais freqüentemente relacionados às ExPEC, em especial às infecções urogenitais de humanos, cães e gatos, encontram-se: O2, O4, 06, 011, 018, 025, 075 e 0102 (BIDET et al., 2007; GRINDLAY et al., 1973; JOHNSON, 1991, 2001b; ORSKOV e ORSKOV, 1985; SMITH et al., 2007; WESTERLUNG et al., 1987; WILKINSON, 1974; WILSON et al., 1988; YURI et al.,1998b).

Embora certos antígenos $\mathrm{O}$ e $\mathrm{K}$ proporcionem uma vantagem adaptativa às amostras de ExPEC, os mecanismos exatos de como estes antígenos atuam na virulência ainda não foram totalmente esclarecidos (WILES et al., 2008).

Na patogênese das ITU ocasionadas por ExPEC, como ilustrada na Figura 1, foram identificados fatores de virulência ( $F V$ ) que possibilitam as amostras colonizar, invadir e/ou evadir o sistema imunológico do hospedeiro. Entre estes FV estão adesinas, invasinas, toxinas, sideróforos e evasinas, contidos em plasmídios ou ilhas de patogenecidade (BOWER et al., 2005; JOHNSON, 1991; KAPER et al., 2004; MULVEY et al., 2000). 
11. E. coli atravessa a barreira de células epiteliais tubulares e inicia a bacteremia
8. Indução de citocinas

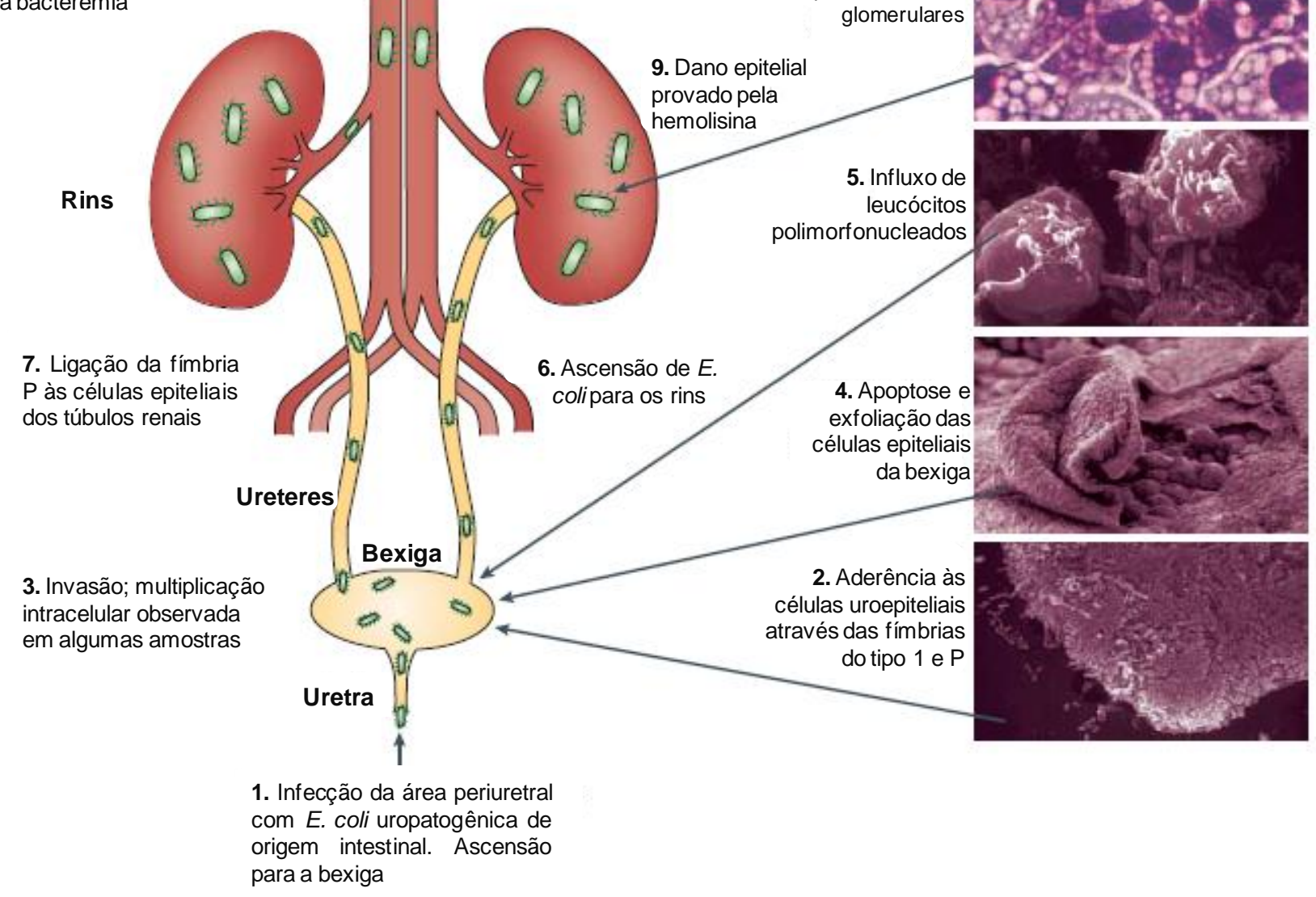

Figura 1. Patogênese da infecção do trato urinário ocasionada por E. coli uropatogênica, onde são ilustrados os diferentes estágios da infecção (adaptado de Kaper et al., 2004).

Um pré-requisito para as EXPEC colonizarem o trato urinário relaciona-se com a habilidade destas amostras se aderirem à superfície do epitélio do hospedeiro, constantemente submetido às forças hidrodinâmicas (LE BOUGUÉNEC et al., 1992; ROOS et al., 2006).

A adesão se faz através de estruturas protéicas presentes na superfície bacteriana que permitem a ligação da bactéria a receptores específicos, presentes nas células do hospedeiro. Estas estruturas, também chamadas adesinas, podem ser organelas filamentosas denominadas pili ou fímbrias, ou se caracterizarem como moléculas monoméricas ou multiméricas ancoradas na parede celular bacteriana, chamadas de adesinas afimbriais (BLANCO e BARTGES, 2001; BOWER et al., 2005). 
Quatro principais tipos de adesinas têm sido associados às ExPEC: fímbria do tipo 1, pilus associado à pielonefrite (fímbrias $P$ ), fímbrias $S$ e Afa adesinas (JOHNSON, 1991; KURAZONO et al. 2003; YURI et al., 1998a).

As fímbrias do tipo 1 são encontradas em diversas espécies de bactérias patogênicas e comensais e têm sido detectados na maioria das amostras que ocasionam infecções urinárias no homem e animais (BOWER et al., 2005; MARTINEZ et al., 2000; YURI et al., 1998a, 2000).

É composta por uma estrutura helicoidal formada por repetidas subunidades da proteína estrutural FimA, ligadas as proteínas FimG e FimF, com uma adesina FimH, codificada pelo gene fimH (SCHILLING et al., 2001; SOKURENKO, 1994). Esta se liga a proteínas $\alpha$-D-manosilatadas, como as uroplaquinas, abundantes na bexiga (BOWER et al., 2005; JOHNSON, 1991; MULVEY et al., 2000; WU et al., 1996). Receptores para esta fímbria também estão presentes em eritrócitos de várias espécies; células do epitélio bucal, intestinal e vaginal; camadas musculares e parede dos vasos sangüíneos. Nos rins são encontrados receptores, principalmente, em túbulos proximais e parede de vasos. Já na bexiga, em camadas musculares e vasos sangüíneos (JOHNSON, 1991).

No teste de hemglutinação, utilizado para verificar a expressão adesinas, a atividade hemaglutinante está associada ligação destas fímbrias a receptores específicos, que podem ser inibidas na presença de D-manose, apresentando o padrão de hemaglutinação MSHA ("Mannose-Sensitive Hemagglutination") (DUGUID et al., 1979; FEIN, 1981; HAGBERG et al., 1981; LE BOUGUÉNEC et al., 2001).

Existem evidências que esta adesina atue como uma invasina. Sua interação com receptores da membrana do hospedeiro desencadeariam vários sinais, entre eles o rearranjo do citoesqueleto da célula eucariótica, que culminaria com a internalização da bactéria (BOWER et al., 2005; MARTINEZ et al., 2000; MULVEY et al., 2000).

O operon pap, que codifica a fímbria $\mathrm{P}$, é composto por 11 genes, seis deles relacionados a proteínas estruturais (PapA, PapH, PapK, PapE, PapF e PapG). Esta fímbria constitui-se na principal adesina associada ao padrão MRHA ("MannoseResistent Hemagglutination"), ou seja, quando a aglutinação ocorre mesmo na 
presença de D-manose. A fímbria $P$ liga-se à porção $\alpha-D-G a l$ (1-4)- $\beta-D-G a l$ glicolípide dos receptores presentes tanto nos rins como nos eritrócitos, e sua expressão é mais frequentemente encontrada em isolados de pacientes acometidos de pielonefrite (BERGSTEN et al. 2005; JOHNSON, 1991). No homem esta fímbria está principalmente associada a processos de pielonefrite $(70 \%)$, sendo menos freqüente em pacientes com cistite (36\%), bacterúria assintomática (24\%) e portadores fecais (19\%). Além disso, $71 \%$ dos isolados com este genótipo foram associados à bacteremia decorrente de ITU (JOHNSON, 1991). Em cães e gatos também foram detectados altos percentuais (ao redor de $50 \%$ ) de amostras positivas para este fator de virulência em animais doentes (LOW et al., 1988; YURI et al., 1998a).

Um terceiro grupo de adesinas - fímbrias $S$ - é encontrado com uma alta incidência em isolados de meningite e utilizam como receptor o ácido siálico, presente nas células epiteliais de túbulos contorcidos proximais e distais, ductos coletores, glomérulos, interstício e endotélio vascular renal (JOHNSON, 1991; OTT et al., 1986). Amostras com este genótipo estiveram presentes em 54\% e 27\% das amostras de UPEC de cães doentes e sadios, respectivamente, estudadas por Yuri et al. (1998a). No mesmo estudo o percentual encontrado em gatos doentes e sadios foi de $60 \%$ e $45 \%$.

Algumas adesinas, denominadas como adesinas afimbriais ou não-fimbriais, estão relacionadas com uma estrutura amorfa associada à membrana externa. Labigne-Roussel et al. em 1984 relataram a presença de uma adesina não fimbrial, com padrão MRHA, em uma amostra que não possuía o operon pap, mas com capacidade de aglutinar eritrócitos de todos os grupos sanguíneos humanos, designando-a como AFA-I ("Afimbrial Adhesin”). O operon para afa apresenta um segmento de $4,1 \mathrm{~Kb}$, altamente conservado, contendo os genes $a f a B$, afaC e afaD, com uma grande variação no gene afaE (LE BOUGUÉNEC e BERTIN, 1999, LE BOUGUÉNEC, 2005).

Esta fímbria, contudo, tem sido associada principalmente à cistite, estando presente em 30-50\% dos pacientes humanos com esta afecção (JOHNSON, 1991). Já em cães e gatos doentes, os percentuais de amostras com este perfil parecem ser baixos, 4\% e 8\%, respectivamente (YURI et al., 1998a). 
Em 2000, TARR e colaboradores descreveram a presença de uma adesina não hemaglutinante em E. coli O157:H7. Neste estudo, os autores verificaram a existência de uma ORF ("Open Reading Frame") capaz de conferir aderência à cepa de $0157: \mathrm{H} 7$, com um conteúdo de $\mathrm{G}+\mathrm{C}$ de $52 \%$. Os aminoácidos codificado por este gene apresentavam 53\% de emparelhamento com os aminoácidos de $\operatorname{IrgA}$. Este atua como receptor do sideróforo enterobactina de Vibrio cholerae, codificado pelo gene irgA ("Iron-Regulated Gene A"). Desta forma, esta proteína de E. coli foi designada como Iha ("IrgA Homologue Adhesin").

Devido à homologia apresentada pela seqüência do gene iha com a ORF R4 na PAI I de E. coli CFT073 - amostra protótipo de UPEC, isolada de sangue e urina de uma paciente com pielonefrite (MOBLEY et al., 1990), este gene passou a ser pesquisado como marcador para esta ilha de patogenecidade. Além disso, é também considerado um fator envolvido na virulência, uma vez que apresenta alta prevalência em isolados de pacientes com bacteremia, não comprometidos imunologicamente (JOHNSON et al., 2000).

As invasinas constituem um importante fator de virulência, especialmente em amostras de $E$. coli relacionadas à meningite neonatal. A proteína codificada pelo gene ibeA, presente na amostra protótipo de meningite RS 218, exerce papel fundamental na invasão do endotélio cerebral sendo, depois da adesão, constitui um dos fatores cruciais da patogênese (BONACORSI e BIGEN, 2005; HUANG et al., 1995).

$\mathrm{Na}$ década de 1980 Caprioli e colaboradores descreveram uma toxina produzida por cepas de E. coli isoladas de crianças com diarréia. Demonstrou-se que esta toxina era citotóxica para células HeLa, ocasionando multinucleação em linhagens celulares e necrose em pele de coelho, recebendo a denominação de CNF1 ("Cytotoxic Necrotizing Factor 1").

Esta toxina impede a divisão celular, sem interferir na replicação do ácido nucléico, formando células dez vezes maiores, com vários núcleos (BLANCO et al., 1992; BLANCO et al., 1996). Após a purificação, o CNF1 foi identificado como uma proteína de membrana de $115 \mathrm{kDa}$, de cadeia simples. Esta toxina do tipo $\mathrm{AB}$, tem a porção N-terminal responsável pela ligação com o receptor celular e a porção Cterminal catalítica, com atividade desamidase e entre elas, uma porção com duas 
alças hidrofóbicas, responsável pela translocação na membrana (BLUMENTHAL et al., 2007; FALBO et al., 1992).

CNF1 pertence à família de toxinas que ativam GTPases através da desamidação da glutamina 63 de RhoA e glutamina 61 de Rac1 e Cdc 42 . Esta ativação induz a formação de fibras de estresse e adesão focal (RhoA), lamelipodia (Rac1) e filopodia (Cdc42), resultando em um rearranjo do citoesqueleto (MCNICHOL et al., 2007).

Além de enterite, observou-se a associação de amostras CNF positivas com infecções extra-intestinais, incluindo septicemia e infecções do trato urinário, tanto em homens como em animais, (ALONSO et al., 1987, 1992; CAPRIOLI et al., 1983).

Há grande correlação entre a produção de CNF1 com outra toxina, a $\alpha$ hemolisina (BOWER et al., 2005; DE RYCKE et al., 1999; SALYERS e WHITT, 2002; YURI et al., 1998a).

A habilidade de algumas amostras de E. coli lisarem eritrócitos de diferentes espécies de mamíferos, conhecida como hemólise, foi primeiramente descrita por Kayser em 1903. Em 1921 foi descrita uma associação entre amostras E. coli e a produção de hemólise em pacientes com infecção do trato urinário (BEUTIN et al., 1991).

A a-hemolisina recebe essa designação graças à sua capacidade de lise de glóbulos vermelhos, formando poros na membrana, promovendo a ruptura da célula com conseqüente liberação de ferro (CAVALIERI et al., 1984; KUCHERIA et al., 2005; SALYERS e WHITT, 2002; YURI et al., 1998a). Vários estudos já comprovaram que a $\alpha$-hemolisina é um importante fator de virulência em amostras isoladas de infecção urinária em cães, gatos e humanos (DRAZENOVICH, 2004; LOW et al, 1988; WILSON et al, 1988; YURI et al, 1998a).

Para atender a necessidade de ferro, geralmente escasso em sua forma livre, alguns microrganismos desenvolveram estratégias de captação e transporte de ferro, como os sideróforos. Alguns sideróforos foram identificados em amostras de $E$. coli que ocasionam ITU, sendo o mais eficiente destes a aerobactina, pequena molécula que extrai o $\mathrm{Fe}^{3+}$ ligado às proteínas dos fluídos do hospedeiro (CROSA, 1989; JOHNSON, 1991; SALYERS e WHITT, 2002). 
A aerobactina é um sistema de seqüestro e transporte de ferro, permitindo o crescimento de E. coli em ambientes limitados deste nutriente. Este sistema de captação de ferro está geralmente associado ao plasmídio ColV-K30 e apresenta alta incidência em isolados de pacientes com bacteremia, septicemia, pielonefrite e meningite (CARBONETTI et al., 1986; JOHNSON, et al., 1988). O operon para aerobactina é composto por cinco genes, cuja transcrição é controlada pelo produto do gene fur, uma proteína repressora que usa o $\mathrm{Fe}^{2+}$ como um co-repressor. Quatro genes (iucA a iucD) estão envolvidos na biosíntese do sideróforo, enquanto o gene iutA determina yn receptor de membrana externa para o complexo ferro-aerobactina (HERRERO et al., 1988).

Estudos recentes identificaram o sistema de captação de ferro utilizado por cepas patogênicas de Yersinia spp., a yersiniabactina, em cepas de ExPEC (JOHNSON e STELL, 2000; KOCZURA e KAZNOWISKI, 2003; SCHUBERT et al., 1998). De fato, uma grande variedade de enterobactérias possui um cluster de genes denominado de HPI ("High-Pathogenicity Island") que codifica proteínas para a biossíntese da yersiniabactina. Neste cluster está presente o gene fyuA ("Ferric Yersiniabactin Uptake"), que codifica FyuA, uma proteína de membrana externa, com função de receptar o complexo Fe-Ybt (ferro-yersiniabactina) (HANCOCK et al., 2008).

Além de aderir e invadir as células do hospedeiro, algumas cepas de ExPEC têm a capacidade de se evadir do sistema imune, sobrevivendo ao soro, devido a presença de componentes na superfície bacteriana, como a proteína de membrana externa TraT, que inibe a ativação do complemento (PRAMOONJAGO et al., 1992; SUKUPOLVI e O'CONNOR, 1990).

O plasmídio ColV tem sido relacionado com aumento de virulência, mais freqüentemente em amostras isoladas de pielonefrite, por apresentar genes de resistência à fagocitose (iss) e complemento (traT), além do sideróforo aerobactina (FERNANDEZ-BEROS et al., 1990; JOHNSON, 1991).

Os genes de virulência podem ser encontrados em transposons, bacteriófagos, plasmídios ou ainda estar inseridos em regiões específicas no cromossomo bacteriano, denominadas Ilhas de Patogenecidade (PAI). Em UPEC já foram descritas PAI nas amostras protótipo de UPEC J96, 536 e CFT073, nas quais 
se encontram genes que codificam adesinas, sideróforos e a a-hemolisina (OELSCHLAEGER et al., 2002; SCHMIDT e HENSEL, 2004).

Através de estudos epidemiológicos, clínicos e de caracterização genética as cepas de Escherichia coli podem ser classificadas em três categorias: comensal, patógeno intestinal e patógeno extra-intestinal. A barreira entre o comensalismo e a virulência resulta de um complexo balanço do estado do hospedeiro com a presença e a expressão de fatores de virulência na bactéria (PICARD et al., 1999; KAPER et al., 2004; EWERS et al., 2007).

Amostras de ExPEC são filogeneticamente e epidemiologicamente distintas das comensais e patogênicas intestinais, pois não são capazes de provocar doenças entéricas, no entanto, podem colonizar assintomaticamente o trato intestinal, correspondendo a $20 \%$ da população em indivíduos normais (SMITH et al., 2007).

Baseado em resultados obtidos por MLEE ("Multi-Locus Enzyme Electrophoresis") demonstrou-se que as amostras de E. coli podem ser agrupadas em quatro principais grupos filogenéticos: A, B1, B2 e D. Uma grande variedade de fatores de virulência associados a isolados de infecções extra-intestinais concentrase em amostras pertencentes aos grupos B2 e D, apresentando maior freqüência e variabilidade do que aquelas pertencentes ao grupo $A$ e B1, associados a amostras comensais (JOHNSON et al., 2001a; JOHNSON e RUSSO, 2002; LE GALL et al., 2007).

Embora este patógeno seja estudado extensivamente, principalmente em infecções humanas, em nosso país não há pesquisa acerca da caracterização de isolados em animais de companhia. 
Este trabalho teve como objetivo a caracterização de amostras de Escherichia coli isoladas em nosso meio, de infecções do trato urinário de cães e gatos, quanto aos sorotipos, genes de virulência e grupos filogenéticos. 


\subsection{Animais}

Durante o período de setembro de 2005 a setembro de 2006 foram colhidas 100 amostras de urina de animais (86 cães e 14 gatos), com suspeita de infecção no trato urinário, provenientes de clínicas de diferentes regiões da cidade de São Paulo. Tais amostras foram oriundas da parceria com a Dra. Maria Christina Christovão Ramos do Laboratório LAB\&VET Diagnóstico e Consultoria LTDA.

Após a colheita, realizada por cistocentese, cateterização ou micção espontânea, as amostras foram acondicionadas em recipientes estéreis, transportadas sob refrigeração e processadas no prazo máximo de 6 horas (BARTGES, 2004; BLANCO e BARTGES, 2001). A urinálise foi realizada pelo LAB\&VET, de acordo as técnicas laboratoriais rotineiras (BARTGES, 2004; MEYER et al., 1995) e, para a cultura, as amostras foram enviadas ao Laboratório de Pesquisa em Clínica e Doenças Infecciosas, Clininfec, da Universidade Paulista (UNIP).

\subsection{Cultura e Identificação Bacteriana}

As amostras de urina foram semeadas em ágar sangue e ágar MacConkey (Difco'). A identificação dos isolados foi realizada de acordo com as técnicas rotineiras de identificação bioquímica (KONEMAN et al., 1997), incluindo os kits de identificação bioquímica EPM, MILi, Citrato, kit para a identificação de Enterococcus spp. e Staphy test (todos da Probac²).

\footnotetext{
${ }^{1}$ BD Difco, New Jersey, EUA

${ }^{2}$ Probac do Brasil, São Paulo, Brasil
} 
A avaliação quantitativa, considerada padrão de referência para ITU (BARTGES, 2004; LULICH e OSBORNE, 2004) determinou o número de colônias bacterianas (Unidades Formadoras de Colônias - UFC) por mililitro de urina. A quantificação bacteriana foi realizada em duas placas de ágar TSA ("Tryptic Soy Agar", Difco), através da semeadura e espalhamento com alça de Drigalski de $10 \mu \mathrm{L}$ e $100 \mu \mathrm{L}$ de urina, respectivamente. Realizou-se a interpretação dos resultados obtidos nas avaliações quantitativas conforme o preconizado por Polzin (1994) e descrito na Tabela 1.

Tabela 1. Interpretação da avaliação quantitativa das culturas bacterianas de urina de cães e gatos.

\begin{tabular}{|c|c|c|c|c|c|c|}
\hline \multirow{3}{*}{$\begin{array}{c}\text { Método de } \\
\text { colheita de } \\
\text { urina }\end{array}$} & \multicolumn{6}{|c|}{ Interpretação dos resultados obtidos na cultura (UFC/ml) } \\
\hline & \multicolumn{2}{|c|}{ Significante } & \multicolumn{2}{|c|}{ Suspeito } & \multicolumn{2}{|c|}{ Contaminante } \\
\hline & Cães & Gatos & Cães & Gatos & Cães & Gatos \\
\hline Cistocentese & $\geq 1.000$ & $\geq 1.000$ & $100-1.000$ & $100-1.000$ & $\leq 100$ & $\leq 100$ \\
\hline Cateterização & $\geq 10.000$ & $\geq 1.000$ & $1.000-10.000$ & $100-1.000$ & $\leq 1.000$ & $\leq 100$ \\
\hline $\begin{array}{l}\text { Micção } \\
\text { Voluntária }\end{array}$ & $\geq 100.000$ & $\geq 10.000$ & $10.000-90.000$ & $1.000-10.000$ & $\leq 10.000$ & $\leq 1.000$ \\
\hline $\begin{array}{l}\text { Compressão } \\
\text { manual }\end{array}$ & $\geq 100.000$ & $\geq 10.000$ & $10.000-90.000$ & $1.000-10.000$ & $\leq 10.000$ & $\leq 1.000$ \\
\hline
\end{tabular}

Do total das 100 amostras de urina colhidas, 43 tiveram o isolamento de bactéria identificada bioquimicamente como Escherichia coli. Três colônias de cada uma das amostras de urina foram enviadas para o Laboratório de Bacteriologia Médica e Veterinária, no Instituto de Ciências Biomédicas II, USP para caracterização genotípica. As colônias foram mantidas tanto em meio de manutenção Ligniéres ${ }^{3}$ como congeladas a $-86{ }^{\circ} \mathrm{C}$ em 1:1 (v/v) de meio $\mathrm{BHI}$ ("Brain Heart Infusion", Difco) e $80 \%$ de glicerol em solução salina (0,85\%).

\footnotetext{
${ }^{3}$ Composição: extrato de carne $(5 \mathrm{~g})$, peptona $(10 \mathrm{~g}), \mathrm{NaCl}(5 \mathrm{~g})$, gelatina $(5 \mathrm{~g})$, ágar bacteriológico $(7 \mathrm{~g})$, água destilada $(1 \mathrm{~L})$. Todos os meios provenientes da Difco
} 


\subsection{Amostras-Padrão}

Em cada um dos experimentos realizados utilizaram-se como controle positivo e negativo as amostras-padrão, conforme descrito na Tabela 2. Antes de cada teste, as cepas foram semeadas em meio TSA e incubadas por 18-24 horas a $37^{\circ} \mathrm{C}$.

\subsection{Sorotipagem}

As amostras de E. coli foram sorotipadas, pela Dra. Kinue Irino no Laboratório de Referência para E. coli do Instituto Adolfo Lutz, com a utilização de anti-soros para os antígenos $\mathrm{O}$ (anti-soros $\mathrm{O} 1$ a 0181 ) e H (anti-soros H1 a H56), de acordo com as técnicas sorológicas internacionalmente padronizadas. 
Tabela 2. Amostras padrão utilizadas na caracterização de E. coli isolada de infecção urinária de cães e gatos, segundo os testes em que foram empregadas, características de virulência, sorotipo e procedência.

\begin{tabular}{|c|c|c|c|c|c|c|c|}
\hline \multirow[b]{2}{*}{ Designação } & \multicolumn{4}{|c|}{ Teste } & \multirow[b]{2}{*}{ Característica } & \multirow[b]{2}{*}{ Sorotipo } & \multirow[b]{2}{*}{ Origem } \\
\hline & $\mathrm{PV}^{\mathrm{P}}$ & $\mathrm{GF}^{2}$ & $\mathrm{HL}^{3}$ & $\mathrm{HM}^{4}$ & & & \\
\hline $\mathrm{K} 12 \mathrm{c} 600$ & $\mathbf{X}$ & $\mathbf{X}$ & $\mathbf{X}$ & $\mathbf{X}$ & $\begin{array}{c}\text { controle negativo } \\
\text { GF A }\end{array}$ & $\mathrm{NF}^{5}$ & Silveira, W. D., Brasil \\
\hline JJ055 & $\mathbf{X}$ & $\mathbf{x}$ & & $\mathbf{x}$ & $\begin{array}{c}\text { controle negativo } \\
\text { derivada de K12, GF A }\end{array}$ & $\mathrm{NF}^{5}$ & $\begin{array}{l}\text { Johnson, J. R., EUA } \\
\text { isolado fecal humano de paciente saudável }\end{array}$ \\
\hline $\mathrm{C} 7$ & $\mathbf{x}$ & & & & pap+, sfa+, cnf1+, hly+ & O18:K1:H7 & $\begin{array}{l}\text { Yamamoto, S., Japão } \\
\text { isolado humano de cistite }\end{array}$ \\
\hline C149 & $\mathbf{x}$ & & & & afa1+, aer+, hly+ & O75:H5 & $\begin{array}{l}\text { Yamamoto, S., Japão } \\
\text { isolado humano de cistite }\end{array}$ \\
\hline JJ079 (J96) & $\mathbf{x}$ & $\mathbf{x}$ & $\mathbf{x}$ & $\mathbf{x}$ & $\begin{array}{l}\text { pap+, sfa+, fimH+, hly+, cnf1+, } \\
\text { fyuA+, tra } T_{+}, \mathrm{PAl}_{\mathrm{CFT} 073}+, \mathrm{GF} \text { B2 }\end{array}$ & $\mathrm{O} 4: \mathrm{K}-\mathrm{H} 5$ & $\begin{array}{l}\text { Johnson, J. R., EUA } \\
\text { isolado humano de pielonefrite }\end{array}$ \\
\hline BUTI 3-1-4 & $\mathbf{x}$ & & & & $\begin{array}{c}\text { sfa+, hly+, cnf1+, fyuA+, trat } T_{+} \\
\text {ibeA+, PAl } \text { CFT073 }^{+}\end{array}$ & O18ac:K1:H7 & $\begin{array}{l}\text { Johnson, J. R., EUA } \\
\text { isolado humano de urosépsis }\end{array}$ \\
\hline BUTI 1-7-6 & $\mathbf{x}$ & & & & $\mathrm{fimH}_{+}$, fyuA+, cvaC+, tra $T_{+}$ & O9:K34:H- & $\begin{array}{l}\text { Johnson, J. R., EUA } \\
\text { isolado humano de urosépsis }\end{array}$ \\
\hline BUTI 1-5-1 & $\mathbf{x}$ & & & & pap+, sfa+, iha+, fimH+, fyu $A_{+}$ & $\mathrm{O} 2: \mathrm{K} 5: \mathrm{H} 1$ & $\begin{array}{l}\text { Johnson, J. R., EUA } \\
\text { isolado humano de urosépsis }\end{array}$ \\
\hline EDL933 & & $\mathbf{x}$ & $\mathbf{x}$ & & $s t x 1+, s t x 2+, e a e+, e h x+$, GF D & O157:H7 & $\begin{array}{l}\text { amostra de coleção } \\
\text { Lab. De Bacteriologia Médica e Veterinária - USP }\end{array}$ \\
\hline EC15 & & $\mathbf{x}$ & & & GF B1 & $\mathrm{NF}^{5}$ & Silva, R. S., Brasil \\
\hline
\end{tabular}




\subsection{Reação em Cadeia da Polimerase}

\subsubsection{Pesquisa de Fatores de Virulência}

A pesquisa de genes que codificam os fatores de virulência reconhecidos de ExPEC foi realizada pela PCR em reações de $50 \mu \mathrm{L}$ contendo: $5 \mu \mathrm{L}$ de DNA molde, lisado por fervura a 10 minutos; $1,5 \mathrm{mM}$ de $\mathrm{MgCl}_{2} ; 0,2 \mathrm{mM}$ de cada uma das 4 dNTP; 1,5 u de Taq DNA polimerase (Fermentas ${ }^{4}$ ) em 10X Taq Buffer com HCl $(100$ mM Tris- $\mathrm{HCl}, \mathrm{pH} 8.8$ a $25^{\circ} \mathrm{C}, 500 \mathrm{mM} \mathrm{KCl}, 0,8 \%$ Nonidet $\mathrm{P} 40^{\mathrm{TM} 5}$ ) e água mili-Q qsp. Os iniciadores para os genes $p a p C$, afal, sfa, papEF, iucD, cnf1 foram utilizados na concentração de 0,4 $\mu \mathrm{M}$ cada um. Já para os genes hlyA, fyuA e iha a concentração de cada um dos iniciadores foi de 0,6 $\mu \mathrm{M}$. As reações foram submetidas ao ciclo de amplificação, no termociclador Eppendorf Mastercycler Gradient ${ }^{\mathrm{TM}}$, sendo inicialmente aquecidas à $94{ }^{\circ} \mathrm{C}$ por 3 minutos, em seguida a 30 ciclos de desnaturação à $94^{\circ} \mathrm{C}$ por 1 minuto, 30 segundos à $63^{\circ} \mathrm{C}$ no anelamento, extensão à $72{ }^{\circ} \mathrm{C}$ por 3 minutos e um ciclo de extensão final de 7 minutos.

Em reações de PCR Multiplex, contendo $2 \mu \mathrm{L}$ de DNA molde, lisado por fervura, $4 \mathrm{mM} \mathrm{MgCl}_{2} ; 0,8 \mathrm{mM}$ de cada um dos 4 dNTPs; 2,5 u de AmpliTaq Gold (Applied Biosystems ${ }^{6}$ ) em GeneAmp 10X PCR Buffer II (100 mM Tris-HCl, pH 8.3, $500 \mathrm{mM} \mathrm{KCl}$ ) foram testados os genes fimH, malX (marcador para PAI I $\mathrm{CFT}_{073}$ ), ibeA, traT, cvaC, em dois "pools" diferentes, conforme descrito por Johnson e Stell (2000). O primeiro "pool" foi composto pelos iniciadores FimH f, FimH r, RPAi f, RPAi r, ibe10 $f$, ibe10 $r$ e o segundo pelos TraT f, TraT $r$, ColV-Cf e ColV-Cr, todos com concentração individual de 0,6 $\mu \mathrm{M}$. O volume final de cada reação foi de $25 \mu \mathrm{L}$. Os ciclos de amplificação consistiram em uma etapa inicial de 12 minutos à $95^{\circ} \mathrm{C}$ para ativação da AmpliTaq Gold, seguida de 25 ciclos de desnaturação (94 ${ }^{\circ} \mathrm{C}, 30 \mathrm{~s}$ ),

\footnotetext{
${ }^{4}$ Fermentas, Inc., Maryland, EUA

${ }^{5}$ Trademark: Shell Chemical Co.

${ }^{6}$ Manufactured for Applied Biosystems by Roche Molecular Systems, Inc., New Jersey, EUA
} 
anelamento $\left(63^{\circ} \mathrm{C}, 30 \mathrm{~s}\right)$ e extensão $\left(68^{\circ} \mathrm{C}, 3 \mathrm{~min}\right)$ e uma etapa de extensão final à $72^{\circ} \mathrm{C}$ por 10 minutos.

$\mathrm{Na}$ Tabela 3 encontram-se descritas as seqüências, tamanho do produto amplificado e referências de cada um dos iniciadores utilizados.

Após a amplificação, as amostras foram submetidas à eletroforese em gel de agarose a 2\% (Bio Basic ${ }^{7}$ ), coradas em brometo de etídio ${ }^{8}$, visualizadas em transiluminador UV e fotografadas pelo sistema EDAS Kodak ${ }^{\mathrm{TM}}$.

\footnotetext{
Bio Basic, Inc., Ontario, Canada

${ }^{8}$ Invitrogen Corporation, Carlsbad, EUA
} 


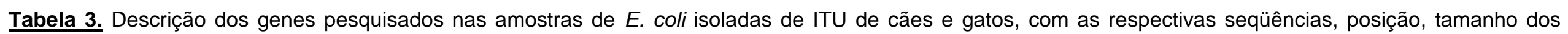
amplificados e referências bibliográficas.

\begin{tabular}{|c|c|c|c|c|c|c|c|}
\hline & Gene & Marcador & Iniciador & Seqüência & Posição & $\begin{array}{l}\text { Tamanho } \\
(\mathrm{pb})^{1}\end{array}$ & Ref. $^{2}$ \\
\hline \multirow{6}{*}{ 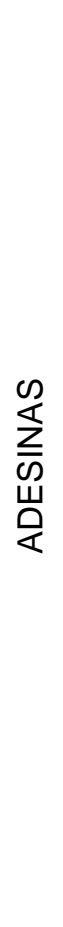 } & $\mathrm{fimH}$ & fímbria do tipo 1 & $\begin{array}{l}\text { FimH f } \\
\text { FimH r }\end{array}$ & $\begin{array}{l}\text { 5' TGCAGAACGGATAAGCCGTGG 3' } \\
\text { 5' GCAGTCACCTGCCCTCCGGTA 3' }\end{array}$ & $\begin{array}{l}1814-1839 \\
2256-2278\end{array}$ & 508 & e \\
\hline & papC & fímbria P & $\begin{array}{l}\text { pap } 1 \\
\text { pap } 2\end{array}$ & $\begin{array}{l}\text { 5' GACGGCTGTACTGCAGGGTGTGGCG 3' } \\
\text { 5' ATATCCTTTCTGCAGGGATGCAATA 3' }\end{array}$ & $\begin{array}{l}(\text { papC) } \\
(\text { papC) }\end{array}$ & 328 & a \\
\hline & papEF & fímbria P & $\begin{array}{l}\text { pap } 3 \\
\text { pap } 4\end{array}$ & $\begin{array}{l}\text { 5’ GCAACAGCAACGCTGGTTGCATCAT 3' } \\
\text { 5' AGAGAGAGCCACTCTTATACGGACA } 3\end{array}$ & $\begin{array}{l}490-514 \\
229-205\end{array}$ & 336 & C \\
\hline & sfa / foc & fímbria S & sfa 1 & $\begin{array}{l}\text { 5' CTCCGGAGAACTGGGTGCATCTTAC 3' } \\
\text { 5' CGGAGGAGTAATTACAAACCTGGCA 3' }\end{array}$ & $\begin{array}{l}(\mathrm{sfaD}) \\
(\mathrm{sfaE})\end{array}$ & 410 & a \\
\hline & afal & adesina afimbrial & $\begin{array}{l}\text { afa } 1 \\
\text { afa } 2\end{array}$ & $\begin{array}{l}\text { 5' GCTGGGCAGCAAACTGATAACTCTC 3' } \\
\text { 5' CATCAAGCTGTTTGTTCGTCCGCCG 3' }\end{array}$ & $\begin{array}{l}(\mathrm{afaB}) \\
(\mathrm{afaC})\end{array}$ & 750 & a \\
\hline & iha & adesina não hemaglutinante & IHA f & $\begin{array}{l}\text { 5' CTG GCG GAG GCT CTG AGA TCA 3' } \\
\text { 5' TCC TTA AGC TCC CGC GGC TGA 3' }\end{array}$ & $\begin{array}{l}3219-3239 \\
4025-4045\end{array}$ & 829 & $f$ \\
\hline$\frac{\nwarrow}{\substack{\infty \\
\vdots}}$ & $i b e A$ & "invasion of brain endothelial cells" & $\begin{array}{l}\text { ibe10 f } \\
\text { ibe10 } r\end{array}$ & $\begin{array}{l}\text { 5' AGG CAG GTG TGC GCC GCG TAC 3' } \\
\text { 5' TGG TGC TCC GGC AAA CCA TGC 3' }\end{array}$ & $\begin{array}{l}261-281 \\
419-439\end{array}$ & 171 & $\begin{array}{l}\mathrm{b} \\
\mathrm{e}\end{array}$ \\
\hline
\end{tabular}


Tabela 3 (continuação)

\begin{tabular}{|c|c|c|c|c|c|c|c|}
\hline & Gene & Marcador & Iniciador & Seqüência & Posição & $\begin{array}{c}\text { Tamanho } \\
(\mathrm{pb})^{1}\end{array}$ & Ref. $^{2}$ \\
\hline \multirow{4}{*}{ 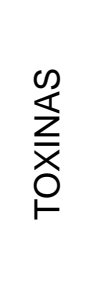 } & \multirow{2}{*}{ cnf1 } & \multirow{2}{*}{ fator citotóxico necrotizante I } & cnf1 & 5' AAGATGGAGTTTCCTATGCAGGAG 3' & $794-817$ & \multirow{2}{*}{498} & c \\
\hline & & & cnf2 & 5' CATTCAGAGTCCTGCCCTCATTATT 3' & $1291-1267$ & & c \\
\hline & \multirow{2}{*}{ hlyA } & \multirow{2}{*}{$\alpha$-hemolisina } & hly 1 & 5' AACAAGGATAAGCACTGTTCTGGCR 3' & $1101-1125$ & \multirow{2}{*}{1177} & c \\
\hline & & & hly 2 & 5' ACCATATAAGCGGTCATTCCCGTCA 3' & $2277-2253$ & & c \\
\hline \multirow{4}{*}{ 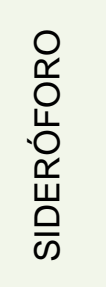 } & \multirow{2}{*}{$i u c D$} & \multirow{2}{*}{ aerobactina } & aer 1 & 5' TACCGGATTGTCATATGCAGACCGT 3' & $143-167$ & \multirow{2}{*}{602} & c \\
\hline & & & aer 2 & 5’ AATATCTTCCTCCAGTCCGGAGAAG 3' & $744-720$ & & c \\
\hline & \multirow{2}{*}{ fyuA } & \multirow{2}{*}{ yersiniabactina } & FyuA $f$ & 5' TGA TTA ACC CCG CGA CGG GAA 3' & $775-795$ & \multirow{2}{*}{787} & e \\
\hline & & & FyuA r & 5' CGC AGT AGG CAC GAT GTT GTA 3' & $1539-1559$ & & $d$ \\
\hline \multirow{3}{*}{ 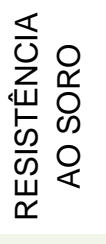 } & \multirow{3}{*}{$\operatorname{traT}$} & \multirow{3}{*}{ proteína de membrana externa TraT } & TraT f & 5' GGT GTG GTG CGA TGA GCA CAG 3' & $461-481$ & \multirow{3}{*}{290} & $\mathrm{e}$ \\
\hline & & & & & & & \\
\hline & & & TraT r & 5' CAC GGT TCA GCC ATC CCT GAG 3' & $728-748$ & & e \\
\hline \multirow{2}{*}{ 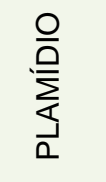 } & \multirow{2}{*}{ cvaC } & \multirow{2}{*}{ Plasmídio ColV } & & 5' CAC ACA CAA ACG GGA GCT GTT 3' & & \multirow{2}{*}{679} & e \\
\hline & & & ColV-Cr & 5' CTT CCC GCA GCA TAG TTC CAT 3' & $679-699$ & & e \\
\hline \multirow{2}{*}{$\bar{\nwarrow}$} & \multirow{2}{*}{$\operatorname{malX}$} & \multirow{2}{*}{ PAI I IFT073 } & RPAi f & 5' GGA CAT CCT GTT ACA GCG CGC A 3' & $1021-1042$ & \multirow{2}{*}{925} & e \\
\hline & & & RPAi $r$ & 5' TCG CCA CCA ATC ACA GCC GAA C 3' & $1921-1942$ & & e \\
\hline
\end{tabular}

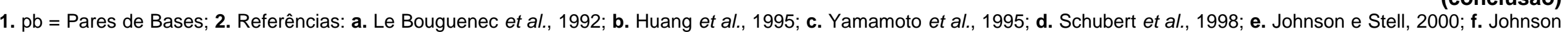
et al., 2000. 


\subsubsection{Determinação de Grupos Filogenéticos}

A classificação dos isolados entre os quatro principais grupos filogenéticos de E. coli (A, B1, B2 e D) foi realizada através da PCR, de acordo com a metodologia descrita por Clermont e colaboradores (2000).

Cada um dos marcadores descritos na Tabela 4 foi testado individualmente, em reações de $50 \mu \mathrm{L}$ contendo: $5 \mu \mathrm{L}$ de DNA molde, lisado por fervura a 10 minutos; 1,5 mM de $\mathrm{MgCl}_{2} ; 0,2 \mathrm{mM}$ de cada uma das 4 dNTP; 0,4 $\mu \mathrm{M}$ de cada iniciador; 1,5 u de Taq DNA polimerase (Fermentas) em 10X PCR Buffer e água mili-Q qsp. Após o ciclo de amplificação, que consistiu de $94{ }^{\circ} \mathrm{C}$ por 5 minutos para a desnaturação inicial e 30 ciclos de desnaturação $\left(30\right.$ segundos a $94^{\circ} \mathrm{C}$ ), anelamento $\left(55^{\circ} \mathrm{C}\right.$ a 30 segundos), extensão $\left(72{ }^{\circ} \mathrm{C}\right.$ a 30 segundos) e 7 minutos a $72{ }^{\circ} \mathrm{C}$ para extensão final, as amostras foram submetidas à eletroforese em gel de agarose (2\%), coradas em brometo de etídio, visualizadas em transiluminador UV e fotografadas pelo sistema EDAS Kodak.

Tabela 4. Descrição dos genes utilizados para classificação de grupos filogenéticos de E. coli, seqüência dos iniciadores e tamanho do fragmento amplificado.

\begin{tabular}{|c|c|c|c|c|}
\hline $\begin{array}{l}\text { Gene / } \\
\text { Fragmento }\end{array}$ & Descrição & Iniciador & Seqüência & $\begin{array}{c}\text { Tamanho } \\
\text { (pb) }\end{array}$ \\
\hline chuaA & $\begin{array}{l}\text { gene necessário para o } \\
\text { transporte de heme em } \\
\text { O157:H7 }\end{array}$ & $\begin{array}{l}\text { ChuA.1 } \\
\text { ChuA.2 }\end{array}$ & $\begin{array}{l}\text { 5' GACGAACCAACGTCAGGAT 3' } \\
\text { 5' TGCCGCCAGTACCAAAGACA 3' }\end{array}$ & 279 \\
\hline yjaA & $\begin{array}{l}\text { gene identificado no genoma } \\
\text { de } E \text {. coli } \mathrm{K}-12 \text {, com função } \\
\text { desconhecida }\end{array}$ & $\begin{array}{l}\text { YjaA.1 } \\
\text { YjaA.2 }\end{array}$ & $\begin{array}{l}\text { 5' TGAAGTGTCAGGAGACGCTG 3' } \\
\text { 5' ATGGAGAATGCGTTCCTCAAC 3' }\end{array}$ & 211 \\
\hline TSPE.4C2 & fragmento anônimo de DNA & $\begin{array}{l}\text { TspE4C2.1 } \\
\text { TspE4C2.2 }\end{array}$ & $\begin{array}{l}\text { 5' GAGTAATGTTCGGGGCATTCA 3' } \\
\text { 5' CGCGCCAACAAAGTATTACG 3' }\end{array}$ & 152 \\
\hline
\end{tabular}


Classificou-se as amostras em um dos grupos filogenéticos $A, B 1, B 2$ ou $D$ de acordo com a interpretação dos resultados das PCRs, segundo a árvore de decisão dicotômica (Figura 2).

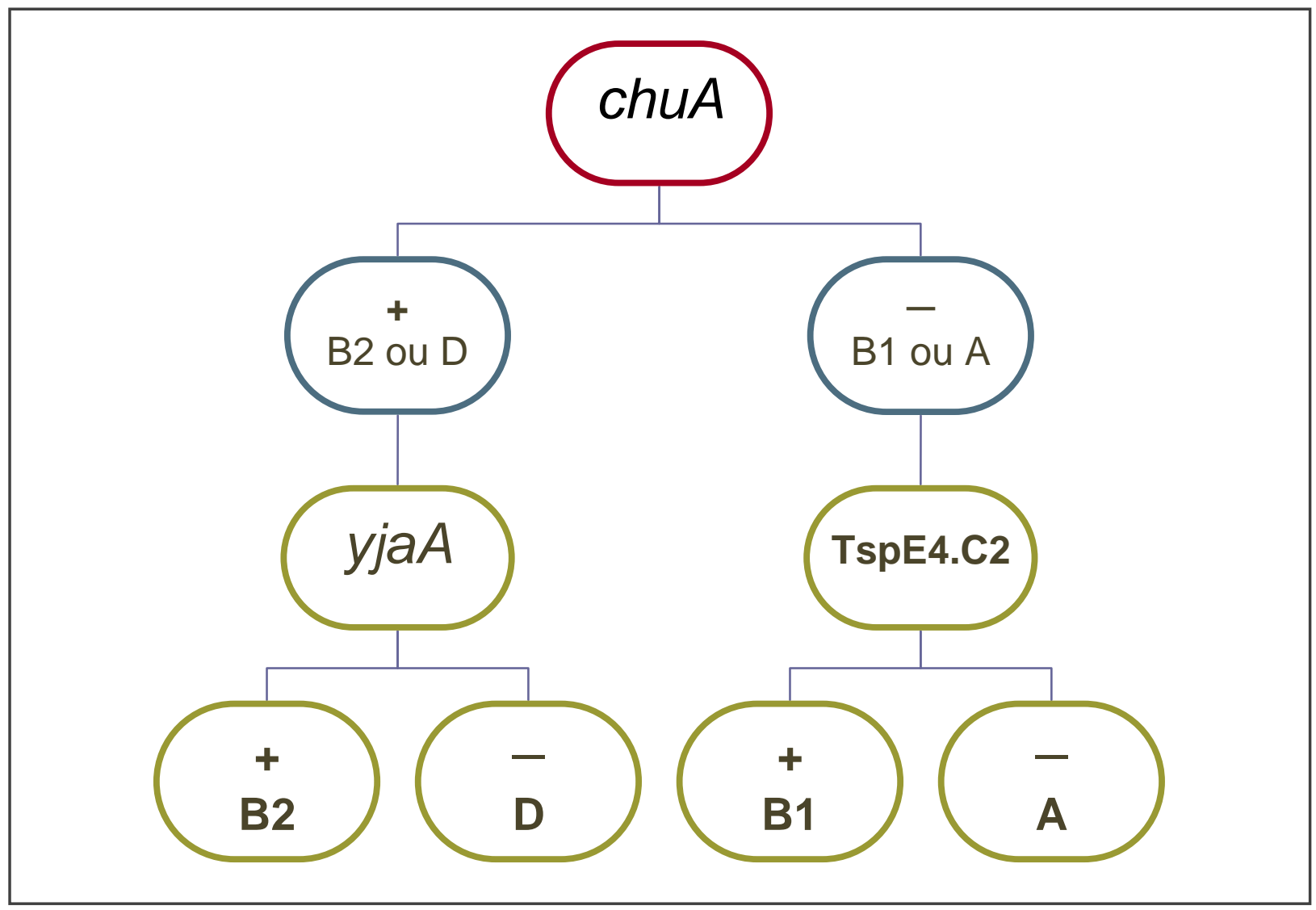

Figura 2. Árvore de decisão dicotômica para determinação do grupo filogenético em amostras de $E$. coli, de acordo com os resultados de PCR para os genes chuA, yjaA e o fragmento de DNA TSPE4.C2 (adaptado de Clermont et al., 2000). 


\subsection{Teste de Produção de Hemolisina}

Para detecção da hemólise, utilizou-se placas de ágar sangue preparadas com base para ágar sangue ("Blood Agar Base", $\mathrm{BBL}^{9}$ ) suplementada com $10 \mathrm{mM}$ de $\mathrm{CaCl}_{2}$ e $5 \%$ de hemácias de carneiro, lavadas 3 vezes em $\mathrm{PBS}^{10}(\mathrm{pH} 7,2)$.

Após o crescimento bacteriano em placas de TSA ( $37^{\circ} \mathrm{C}$ por $18-24$ horas) as colônias foram semeadas nas placas de ágar sangue e incubadas a $37^{\circ} \mathrm{C}$, realizando-se a leitura das mesmas em 3 e 24 horas. As amostras que apresentaram zona de hemólise em 3 horas foram classificadas como $\alpha$-hemolíticas e aquelas que só apresentaram hemólise após 24 horas de incubação, como enterohemolíticas (BEUTIN et al., 1986).

\subsection{Teste de Hemaglutinação}

Verificou-se a expressão de adesinas fimbriais através da técnica de hemaglutinação em lâmina, descrita por Evans e colaboradores em 1979. Inicialmente, as amostras de E. coli foram semeadas em ágar TSA (Difco) e incubadas por $18-24$ horas a $37 \stackrel{\circ}{\mathrm{C}}$. A suspensão bacteriana foi preparada adicionando-se a $100 \mu \mathrm{L}$ de solução de PBS (pH 7,2), alíquota da cultura preparada em ágar TSA, retirada com auxílio de um palito de dente estéril.

O sangue humano do tipo $A$ foi colhido de voluntários, em tubos contendo citrato de sódio (Vacuum II) e diluído em 1:4 em PBS para testar a aglutinação sensível a manose (MSHA) e em 1:4 em 1\% de D-manose ${ }^{11}$ (peso / volume) em PBS para verificação de hemaglutinação resistente à manose (MRHA).

O teste foi realizado em temperatura ambiente, adicionando-se à lâmina de vidro para microscopia, $20 \mu \mathrm{L}$ da suspensão de hemácias com manose e, ao lado,

\footnotetext{
${ }^{9}$ BD-BBL, New Jersey, EUA

${ }^{10}$ Composição PBS: $\mathrm{KH}_{2} \mathrm{PO}_{4}-210$ mg; NaCl -9000 mg; $\mathrm{Na}_{2} \mathrm{HPO}_{4} .7 \mathrm{H}_{2} \mathrm{O}-726$ mg; água destilada $-1 \mathrm{~L}$.

${ }^{11}$ Bio Basic, Ontario, Canadá
} 
outros $20 \mu \mathrm{L}$ da suspensão de hemácias sem manose. Sobre cada suspensão foram acrescidos $20 \mu \mathrm{L}$ da suspensão bacteriana, homogeneizando-as com o auxílio da ponteira. Nos casos em que a hemaglutinação não ocorreu em até 1 minuto, as lâminas foram colocadas sobre gelo e observadas durante 2 minutos, com rotação constante da lâmina.

Os resultados foram avaliados segundo a seguinte escala crescente: 0 , quando não houve nenhuma aglutinação, 1+ (aglutinação lenta e fraca), 2+ (moderada), 3+ (intensa) e 4+, caracterizada por uma hemaglutinação instantânea e completa, envolvendo todos os eritrócitos.

As amostras foram consideradas como MRHA quando a hemaglutinação apresentou o mesmo valor tanto na presença como na ausência de manose. Desta mesma forma, foram consideradas MSHA as amostras cuja presença da manose inibiu ou reduziu a hemaglutinação. 


\section{Resultados}

Das 100 colheitas de urina realizadas, confirmou-se através da urinálise e avaliação microbiológica a presença de ITU em 72 animais, correspondendo a 61 cães e 11 gatos.

Os resultados da urinálise, associados à quantificação de bactérias presentes na urina, demonstraram que todas as colheitas eram compatíveis com o quadro de ITU. A grande maioria das amostras, independente do tipo de colheita, apresentou contagens bacterianas acima de 100.000 UFC/mL. Três indivíduos, que foram classificados como "suspeitos" (80, 89 e 95) pela avaliação bacteriana quantitativa, tiveram resultados de urinálise compatíveis com infecções das vias urinárias (hematúria e/ou piúria) (Tabela 5).

Dos 72 animais, 33 cães $(33 / 61=54 \%)$ e sete gatos $(7 / 11=64 \%)$ apresentaram E. coli como agente etiológico da infecção. Em dois cães ocorreram respectivamente, duas (70 e 77) e três (23, 42 e 49) colheitas, com intervalos de aproximadamente 20 dias, para acompanhamento após a terapia antibacteriana, obtendo-se o isolamento de E. coli em todas essas. Desta forma, dos 40 animais com ITU, o número de colheitas estudadas foi de 43 , sete provenientes de animais da espécie felina e 36 de origem canina.

Dentre as 43 amostras, a E. coli apresentou-se como o único microrganismo isolado em 34 amostras (79\%). As infecções mistas foram encontradas em uma amostra de origem felina (amostra 36) e oito amostras caninas (amostras 53, 58, 60, $64,75,82,90$ e 97), correspondendo respectivamente a 14\% (1/7) e $22 \%(8 / 36)$ do total de amostras de cada espécie.

$\mathrm{Na}$ Tabela 5 encontram-se descritas a caracterização completa das 43 colheitas de urina, os principais dados da urinálise e a avaliação quantitativa e qualitativa das culturas de urina. 


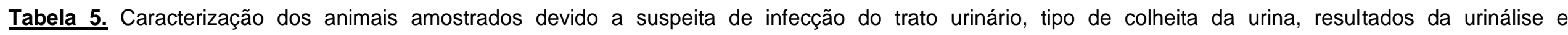
microrganismos isolados.

\begin{tabular}{|c|c|c|c|c|c|c|c|c|c|c|c|}
\hline Amostra & Espécie $^{1}$ & Idade $^{2}$ & $\operatorname{Raça}^{2,3}$ & Sexo & $\begin{array}{c}\text { Tipo de } \\
\text { Colheita }^{3,4}\end{array}$ & Densidade & Proteína & $\begin{array}{l}\text { Jrinálise } \\
\qquad \text { Hemácias } \\
(\text { campo de } 400 x)^{5}\end{array}$ & $\begin{array}{c}\text { Leucócitos } \\
(\text { campo de 400x) }\end{array}$ & $\begin{array}{l}\text { Contagem } \\
\text { (UFC/mL) }^{7}\end{array}$ & $\begin{array}{l}\text { solamento } \\
\text { № da colônia / agente }\end{array}$ \\
\hline 9 & C & $8 a 7 m$ & Poodle & $\pi$ & $\mathrm{Ci}$ & 1038 & +-- & $1-3$ & 6-8 & $>10.000$ & 9/1 E. coli \\
\hline 11 & $\mathrm{C}$ & $9 a 7 m$ & SRD & $\delta$ & $\mathrm{Ci}$ & 1020 & ++ & campo cheio & $35-38$ & $>100.000$ & 11/1 E. coli \\
\hline 15 & $\mathrm{C}$ & $8 a$ & SRD & $\pi$ & $\mathrm{Ci}$ & 1014 & ++- & incontáveis & $14-16$ & $>100.000$ & 15/1 E. coli \\
\hline 20 & C & $11 \mathrm{a} 9 \mathrm{~m}$ & SRD & $\pi$ & $\mathrm{Ci}$ & 1035 & +++ & campo cheio & campo cheio & $>100.000$ & 20/1 E. coli \\
\hline $23^{a}$ & C & $7 a$ & Beagle & $\pi$ & $\mathrm{Ca}$ & 1008 & negativo & $10-15$ & $10-13$ & $>100.000$ & 23/1 E. coli \\
\hline 29 & $\mathrm{C}$ & $7 a 1 m$ & SRD & ? & $\mathrm{Ci}$ & 1028 & negativo & $1-3$ & $12-15$ & $>100.000$ & 29/1 E. coli \\
\hline 36 & $\mathrm{~F}$ & $10 a$ & SRD & $\hat{0}$ & $\mathrm{Ca}$ & 1018 & negativo & $2-4$ & $8-10$ & 25.000 & $\begin{array}{c}36 / 1 \text { E. coli } \\
\text { 36/2 Chryseobacterium } \\
\text { meningosepticum }\end{array}$ \\
\hline 38 & C & $16 a$ & SRD & $\pi$ & $\mathrm{Ca}$ & 1018 & negativo & $7-10$ & campo cheio & $>100.000$ & 38/1 E. coli \\
\hline 40 & C & $12 a$ & SRD & & ME & 1046 & negativo & $0-2$ & $20-23$ & $>100.000$ & 40/1 E. coli \\
\hline 41 & C & NR & Rottweiler & 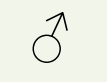 & $\mathrm{Ca}$ & 1040 & ++- & $1-3$ & $6-8$ & $>100.000$ & 41/1 E. coli \\
\hline $42^{a}$ & C & $7 a$ & Beagle & $\pi$ & $\mathrm{Ci}$ & 1022 & +- & campo cheio & campo cheio & $>100.000$ & 42/1 E. coli \\
\hline 45 & C & NR & NR & $\pi$ & NR & & & NR & NR & $>100.000$ & 45/1 E. coli \\
\hline 46 & C & NR & Schnauzer & q & $\mathrm{Ci}$ & $>1050$ & ++++ & $1-3$ & $10-15$ & $>100.000$ & $\begin{array}{l}\text { 46/1 E. coli } \\
\text { (continua) }\end{array}$ \\
\hline
\end{tabular}


Tabela 5 (continuação)

\begin{tabular}{|c|c|c|c|c|c|c|c|c|c|c|c|}
\hline \multirow{2}{*}{ Amostra } & \multirow{2}{*}{ Espécie $^{1}$} & \multirow{2}{*}{ Idade ${ }^{2}$} & \multirow{2}{*}{$\operatorname{Raça}^{2,3}$} & \multirow{2}{*}{ Sexo } & \multirow{2}{*}{$\begin{array}{c}\text { Tipo de } \\
\text { Colheita }^{3,4}\end{array}$} & \multicolumn{4}{|c|}{ Urinálise } & \multicolumn{2}{|r|}{ Isolamento } \\
\hline & & & & & & Densidade & Proteína & $\begin{array}{c}\text { Hemácias } \\
(\text { campo de } 400 x)^{5}\end{array}$ & $\begin{array}{c}\text { Leucócitos } \\
(\text { campo de 400x) }\end{array}$ & $\begin{array}{l}\text { Contagem } \\
(\text { UFC/mL) })^{7}\end{array}$ & № da colônia / agente \\
\hline $49^{a}$ & C & $7 a$ & Beagle & $\hat{0}$ & $\mathrm{Ca}$ & 1012 & negativo & $10-13$ & campo cheio & $>100.000$ & 49/1 E. coli \\
\hline 50 & $\mathrm{~F}$ & $12 a$ & Siamês & 9 & $\mathrm{Ci}$ & 1010 & +- & $2-4$ & $8-12$ & $>100.000$ & 50/1 E. coli \\
\hline 52 & $\mathrm{~F}$ & $6 a$ & SRD & 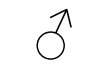 & $\mathrm{ME}$ & $>1050$ & +++ & $10-13$ & campo cheio & $>100.000$ & 52/1 E. coli \\
\hline 53 & C & NR & $\begin{array}{l}\text { Pastor } \\
\text { Alemão }\end{array}$ & & $\mathrm{Ca}$ & 1020 & +++ & campo cheio & campo cheio & $>100.000$ & $\begin{array}{c}53 / 1 \text { E. coli } \\
\text { 53/2 Citrobacter freundii }\end{array}$ \\
\hline 55 & C & $5 a 8 m$ & SRD & 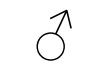 & $\mathrm{Ci}$ & 1050 & ++++ & campo cheio & campo cheio & $>100.000$ & 55/1 E. coli \\
\hline 56 & C & $9 a$ & SRD & 9 & $\mathrm{Ci}$ & 1010 & + & $10-15$ & campo cheio & $>100.000$ & 56/1 E. coli \\
\hline 57 & $\mathrm{~F}$ & $16 a$ & Siamês & ? & $\mathrm{Ci}$ & 1014 & ++- & campo cheio & campo cheio & $>100.000$ & 57/1 E. coli \\
\hline 58 & $\mathrm{C}$ & $11 \mathrm{a} 8 \mathrm{~m}$ & Dachshund & q & $\mathrm{Ci}$ & 1024 & +-- & campo cheio & campo cheio & $>100.000$ & $\begin{array}{c}\text { 58/1 Streptococcus sp } \\
\text { 58/2 Proteus mirabilis } \\
\text { 58/3 E. coli }\end{array}$ \\
\hline 59 & C & $13 a$ & SRD & $\Uparrow$ & $\mathrm{ME}$ & 1012 & +-- & $0-3$ & campo cheio & $>100.000$ & 59/1 E. coli \\
\hline 60 & C & $7 a$ & Schnauzer & $q$ & $\mathrm{Ci}$ & 1014 & +++ & $1-3$ & $6-8$ & $>100.000$ & $\begin{array}{c}\text { 60/1 Staphylococcus coag- } \\
60 / 2 \text { E. coli }\end{array}$ \\
\hline 61 & $\mathrm{~F}$ & $11 a$ & Siamês & $\hat{0}$ & ME & 1018 & ++- & campo cheio & campo cheio & $>100.000$ & 61/1 E. coli \\
\hline 64 & C & $10 a$ & SRD & $\hat{\jmath}$ & $\mathrm{ME}$ & 1010 & negativo & campo cheio & $35-40$ & $>100.000$ & $\begin{array}{c}\text { 64/1 Staphylococcus sp } \\
64 / 2 \text { E. coli }\end{array}$ \\
\hline
\end{tabular}

(continua) 
Tabela 5 (continuação)

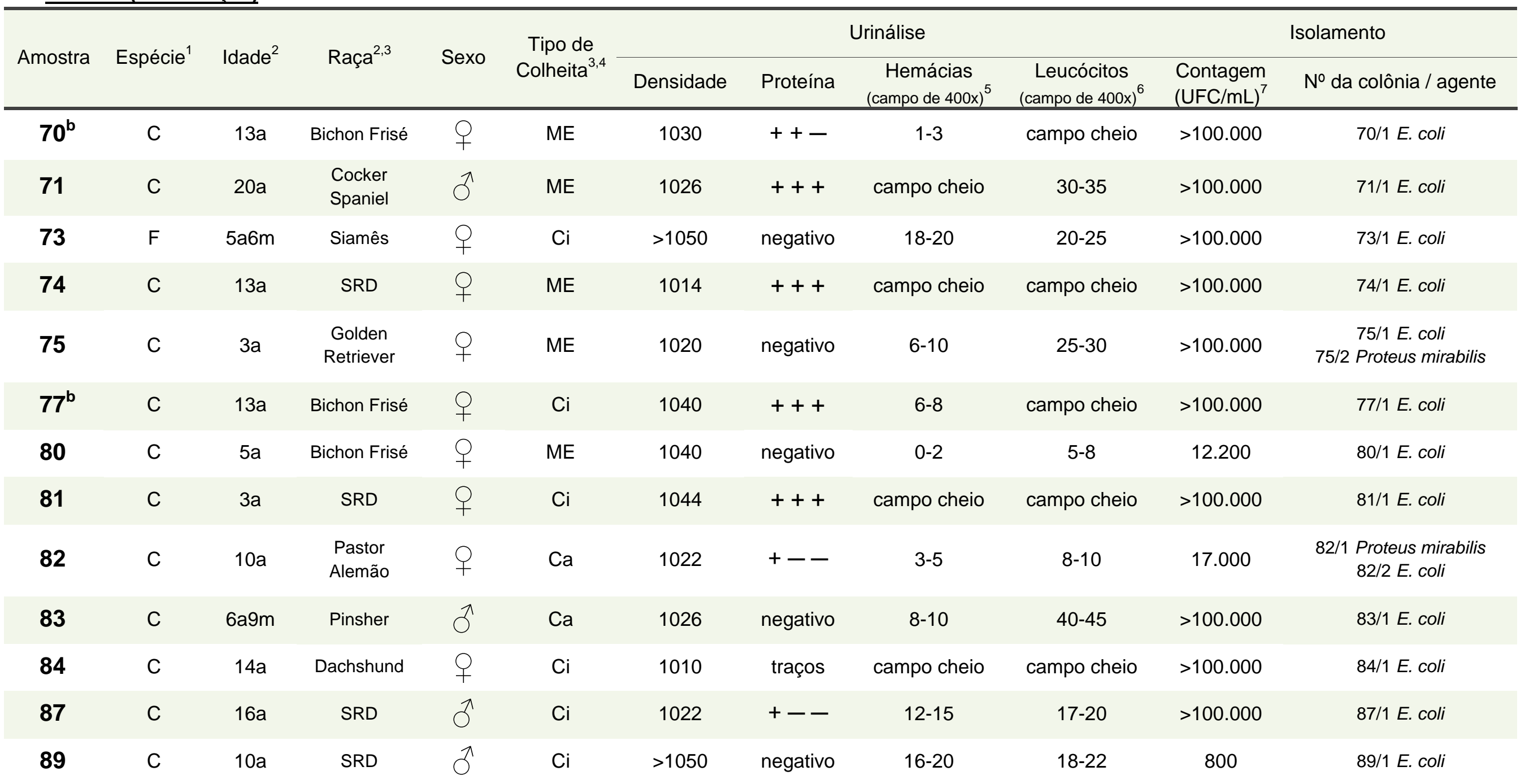

(continua) 
Tabela 5 (continuação)

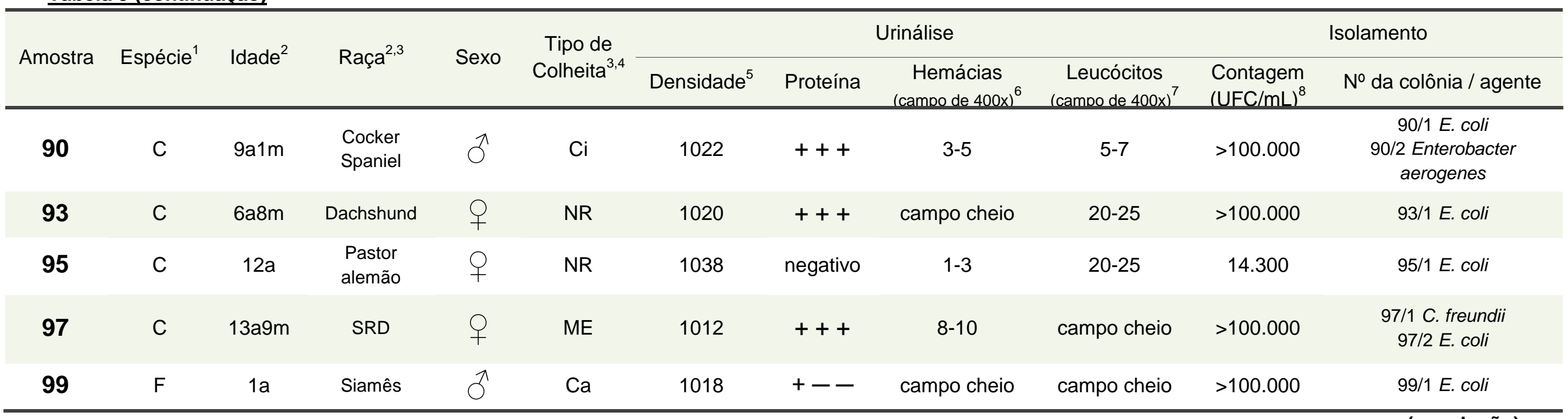

(conclusão)

Legenda:

(a) Amostras colhidas do mesmo animal, nas seguintes datas: 12/08/2005 (23); 23/09/2005 (42); 10/10/2005 (49);

(b) Amostras colhidas do mesmo animal, nas seguintes datas: 04/03/2006 (70); 24/03/2006 (77)

(1) C - canina; F - felina;

(2) NR - não relatado;

(3) SRD - sem raça definida;

(4) C - cistocentese; Ca - cateterismo; ME - micção espontânea;

Valores de referência:

(5) Densidade específica $=1030$ (cão) e 1035 (gato) (MEYER et al., 1995)

(6) Normal $=0-3$ eritrócitos / cga; hematúria = acima de 3 eritrócitos / cga (BARSANTI E FINCO, 1979)

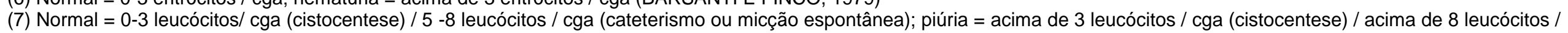
cga (cateterismo ou micção espontânea) (BARSANTI E FINCO, 1979)

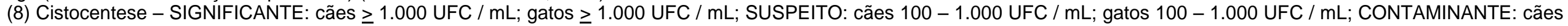
$<100$ UFC / mL; gatos < 100 UFC / mL (POLZIN, 1994);

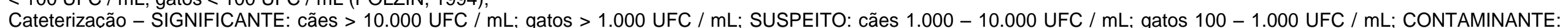
cães < 1.000 UFC / mL; gatos < 100 UFC / mL (POLZIN, 1994);

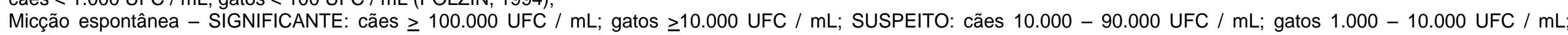
CONTAMINANTE: cães < 10.000 UFC / mL; gatos < 1.000 UFC / mL (POLZIN̄, 1994) 
Considerando-se que das 43 colheitas isolaram-se três colônias de $E$. coli de cada uma, 129 cepas foram sorotipadas e submetidas à pesquisa de genes de virulência. A pesquisa de FV pela PCR e a sorotipagem de cada uma das três colônias isoladas indicou a predominância de um único clone, com o mesmo perfil de virulência, excetuando-se a amostra 50 , onde cada colônia apresentou um sorotipo diferente (O2:H4, O2:H8 e O2:H-), embora semelhantes quanto ao perfil genotípico de virulência (Figura 3). Assim, o universo dos isolados pesquisados correspondeu a 45 cepas, ou seja, um isolado para cada uma das 42 colheitas e três isolados da colheita de $n^{\circ} 50$ (Tabela 6).

Das 45 cepas de $E$. coli, foi possível determinar o sorogrupo de 29 (29/45 = $64 \%)$ cepas. Três cepas $(3 / 45=7 \%)$ apresentaram O rugoso (OR) e em 13 (13/45 = 29\%) amostras não foi possível tipificar o antígeno 0.

Dentre as amostras tipificadas, foram encontrados os seguintes sorogrupos, relacionados às infecções extra-intestinais, em especial as ITU: O6 com nove isolados, sete pertencentes ao sorogrupo 02 , duas amostras dos sorogrupos 021 , O25, $\mathrm{O} 83$ e uma amostra de cada um dos sorogrupos $\mathrm{O} 4, \mathrm{O} 11, \mathrm{O} 15, \mathrm{O} 18, \mathrm{O} 20, \mathrm{O} 23$ e 0153 (Tabela 6).

A caracterização genotípica dos isolados demonstrou que todas as amostras estudadas apresentavam pelo menos um dos genes que codificam os FV pesquisados. Entre estes fatores, a fímbria do tipo 1, detectada através da PCR para o gene fimH, esteve presente em $100 \%$ das amostras. As demais adesinas apresentaram a seguinte freqüência: 47\% (21/45) de amostras positivas para pelo menos um dos genes pesquisados do operon pap (papC e papEF), 33\% (15/45) de amostras positivas para o gene sfa e 4\% (2/45) para o gene iha. Nenhuma amostra foi positiva para o gene afal. Observou-se uma correlação entre a presença dos genes pap e sfa nas amostras dos sorogrupos O2, O4, O6, O18, 021 e O25, com 16 das 19 amostras pap+ e 13 das 15 amostras sfa+ (Tabela 6).

Dentre os genes relacionados aos sideróforos pesquisados (Tabela 6), a yersiniabactina foi mais freqüente $(36 / 45=80 \%)$ do que a aerobactina $(10 / 45=$ $22 \%)$. Das amostras fyuA $A^{+}, 89 \%$ (32/36) apresentaram somente este sideróforo; por outro lado a freqüência das amostras positivas apenas para iucD foi de $20 \%(2 / 10)$. 
Oito amostras $(49,50 \mathrm{a}, 50 \mathrm{~b}, 50 \mathrm{c}, 57,61,64,83)$ foram positivas tanto para fyuA como para iucD (18\%). Em 13\% (6/45) das cepas nenhum dos dois genes pesquisados foi identificado.

Dos marcadores para toxinas, cnf1 apresentou a freqüência de 31\% (14/45) e hlyA, de $27 \%$ (12/45). Observou-se uma correlação entre os dois genes, onde todas as amostras $h l y A^{+}$também apresentaram o gene cnf1. A exceção ocorreu apenas em duas amostras (38 e 93) que possuíam apenas a seqüência para o gene $\mathrm{cnf1}^{+}$(Tabela 6). A presença destes marcadores restringiu-se às amostras pertencentes aos sorogrupos $\mathrm{O} 2, \mathrm{O} 4, \mathrm{O} 6, \mathrm{O} 21$ e $\mathrm{O} 25$.

O plasmídio ColV ( $\mathrm{cvaC}$ ) mostrou-se presente em 20\% (9/45) das amostras; em 23 dos 45 isolados (51\%) detectou-se o gene traT, relacionado à sobrevivência ao soro e 67\% (30/45) apresentaram a seqüência relacionada a PAl de amostras uropatogênicas (malX). A freqüência de ibeA foi de $29 \%$ (13/45), conforme dados apresentados na Tabela 6.

Das 45 amostras, três (amostras 15, 45 e 75) apresentaram apenas o gene fimH; 93\% (42/45) apresentaram mais de um dos genes pesquisados. Houve uma grande variação de genótipos em relação aos 14 genes pesquisados, com associações de dois a nove genes em 26 combinações diferentes.

Observou-se que associações entre os genes sfa + hlyA + cnf $1+$ malX + $\mathrm{fimH}+$ fyuA apresentaram-se em $27 \%(12 / 45)$ das amostras e os genes $\mathrm{cvaC}$ e traT apresentaram-se em conjunto em 6 das 45 amostras (13\%). Todas as amostras positivas para PAI IFF073 ( $m a / X)$ também apresentavam o gene fyuA.

As amostras 70 e 77 (Figura 4), provenientes de um mesmo animal,

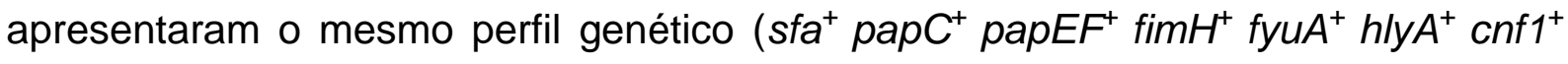
tra $^{+}$mal $X^{+}$) e o mesmo sorogrupo (O6). Da mesma forma, observou-se a semelhança entre as duas primeiras amostras (23 e 42) colhidas do cão da raça

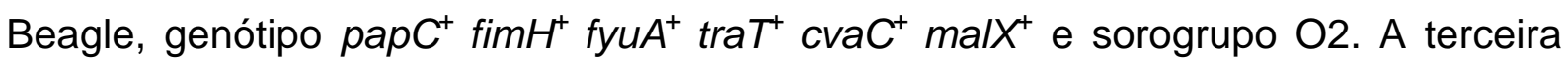
amostra (49), entretanto, apresentou dois outros marcadores $\left(p a p E F^{+} i u c D^{+}\right)$além dos seis anteriores, e o sorogrupo não pode ser determinado (ONT:HNT). 


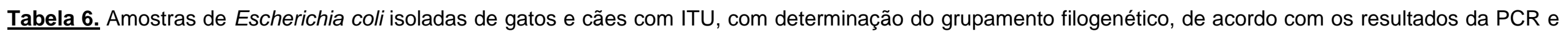
análise de acordo com a árvore de decisão dicotômica, sorotipo e resultado da pesquisa de marcadores de FV pela PCR.

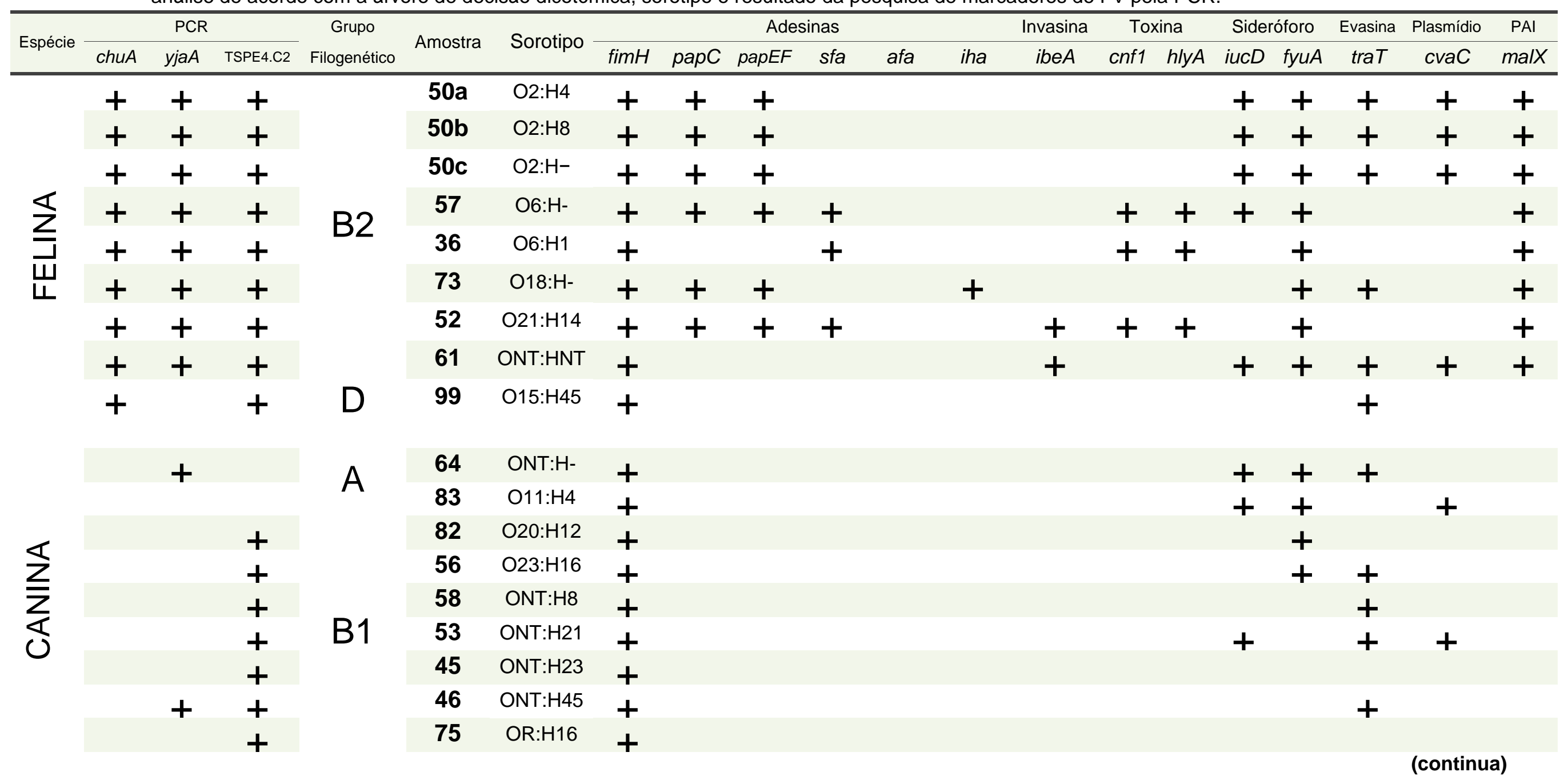


Tabela 6 (continuação)

\begin{tabular}{|c|c|c|c|c|c|c|c|c|c|c|c|c|c|c|c|c|c|c|c|c|}
\hline \multirow{2}{*}{ Espécie } & \multicolumn{3}{|c|}{ PCR } & \multirow{2}{*}{$\begin{array}{c}\text { Grupo } \\
\text { Filogenético }\end{array}$} & \multirow{2}{*}{ Amostra } & \multirow{2}{*}{ Sorotipo } & \multicolumn{6}{|c|}{ Adesinas } & \multirow{2}{*}{$\begin{array}{c}\text { Invasina } \\
\text { ibeA }\end{array}$} & \multicolumn{2}{|c|}{ Toxina } & \multicolumn{2}{|c|}{ Sideróforo } & \multirow{2}{*}{$\begin{array}{c}\text { Evasina } \\
\text { traT }\end{array}$} & \multirow{2}{*}{$\begin{array}{c}\text { Plasmídio } \\
\text { cvaC }\end{array}$} & \multirow{2}{*}{$\begin{array}{l}\text { PAl } \\
\text { malX }\end{array}$} \\
\hline & chuA & yjaA & TSPE4.C2 & & & & $\mathrm{fimH}$ & papC & papEF & sfa & afa & iha & & cnf1 & hlyA & $i u c D$ & fуuA & & & \\
\hline \multirow{20}{*}{$\frac{\pi}{Z}$} & + & + & + & \multirow{20}{*}{ B2 } & 29 & $\mathrm{O} 2: \mathrm{H} 6$ & + & & & + & & & + & + & + & & + & & & + \\
\hline & + & + & + & & 84 & $\mathrm{O} 2: \mathrm{H} 31$ & + & & & & & & + & & & & + & + & & + \\
\hline & + & + & & & 38 & $\mathrm{O} 4: \mathrm{H}-$ & + & + & + & + & & & & + & & & + & & & + \\
\hline & + & + & + & & 9 & $\mathrm{O} 6 \mathrm{H}-$ & + & + & + & + & & & & & & & + & & & + \\
\hline & + & + & + & & 40 & $\mathrm{O} 6: \mathrm{H}-$ & + & + & + & + & & & & + & + & & + & & & + \\
\hline & + & + & + & & 59 & $\mathrm{O} 6: \mathrm{H}-$ & + & + & + & + & & & & + & + & & + & & & + \\
\hline & + & + & + & & $70^{b}$ & $\mathrm{O} 6: \mathrm{H}-$ & + & + & + & + & & & & + & + & & + & + & & + \\
\hline & + & + & + & & 80 & $\mathrm{O} 6 \mathrm{H}-$ & + & + & + & + & & & & + & + & & + & & & + \\
\hline & + & + & + & & $77^{b}$ & O6:H31 & + & + & + & + & & & & + & + & & + & + & & + \\
\hline & + & + & + & & 93 & O6:H31 & + & + & + & & & & + & + & & & + & + & & + \\
\hline & + & + & + & & 55 & $\mathrm{O} 21: \mathrm{H} 14$ & + & + & + & + & & & + & + & + & & + & & & + \\
\hline & + & + & + & & 11 & O25:H11 & + & + & + & + & & + & & + & + & & + & & & + \\
\hline & + & + & + & & 71 & O25:HNT & + & & & & & & + & & & & + & + & & + \\
\hline & + & + & + & & 41 & O83:H31 & + & & & & & & + & & & & + & + & & + \\
\hline & + & + & + & & 60 & O83:H31 & + & & & & & & + & & & & + & + & & + \\
\hline & + & + & + & & 95 & ONT:H4 & + & & & + & & & + & & & & + & + & & + \\
\hline & + & + & + & & 89 & ONT:H45 & + & & & & & & & & & & + & & & + \\
\hline & + & + & + & & 90 & ONT:H45 & + & & & & & & & & & & + & & & + \\
\hline & + & + & + & & 74 & ONT:HNT & + & & & & & & + & & & & + & + & & \\
\hline & + & + & + & & 87 & OR:H? & + & + & + & + & & & + & + & + & & + & & 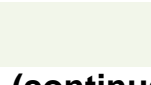 & + \\
\hline
\end{tabular}


Tabela 6 (continuação)

\begin{tabular}{|c|c|c|c|c|c|c|c|c|c|c|c|c|c|c|c|c|c|c|c|c|}
\hline \multirow{2}{*}{ Espécie } & \multicolumn{3}{|c|}{ PCR } & \multirow{2}{*}{$\begin{array}{c}\text { Grupo } \\
\text { Filogenético }\end{array}$} & \multirow{2}{*}{ Amostra } & \multirow{2}{*}{ Sorotipo } & \multicolumn{6}{|c|}{ Adesinas } & \multirow{2}{*}{$\begin{array}{c}\text { Invasina } \\
\text { ibeA }\end{array}$} & \multicolumn{2}{|c|}{ Toxina } & \multicolumn{2}{|c|}{ Sideróforo } & \multirow{2}{*}{$\begin{array}{c}\text { Evasina } \\
\text { traT }\end{array}$} & \multirow{2}{*}{$\begin{array}{c}\text { Plasmídio } \\
\text { cvaC }\end{array}$} & \multirow{2}{*}{$\begin{array}{l}\text { PAI } \\
\text { malX }\end{array}$} \\
\hline & chuA & $y j a A$ & TSPE4.C2 & & & & $\mathrm{fimH}$ & papC & papEF & sfa & afa & iha & & cnf1 & hlyA & $i u c D$ & fyuA & & & \\
\hline \multirow{7}{*}{ 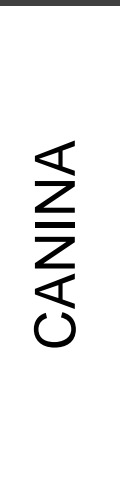 } & + & & & & $23^{a}$ & O2:HNT & + & + & & & & & & & & & + & + & + & + \\
\hline & + & & & & $42^{a}$ & O2:HNT & + & + & & & & & & & & & + & + & + & + \\
\hline & + & & & & 81 & O153:H34 & + & & & & & & + & & & + & & & & \\
\hline & + & & + & & 20 & ONT:H4 & + & + & + & & & & & & & & & & & \\
\hline & + & & + & & 15 & ONT:H6 & + & & & & & & & & & & & & & \\
\hline & + & & & & $49^{a}$ & ONT:HNT & + & + & + & & & & & & & + & + & + & + & + \\
\hline & + & & + & & 97 & OR:H- & + & & & & & & & & & & + & & & \\
\hline
\end{tabular}

Legenda:

(a) Amostras colhidas do mesmo animal, nas seguintes datas: 12/08/2005 (23); 23/09/2005 (42); 10/10/2005 (49);

(b) Amostras colhidas do mesmo animal, nas seguintes datas: 04/03/2006 (70); 24/03/2006 (77) 


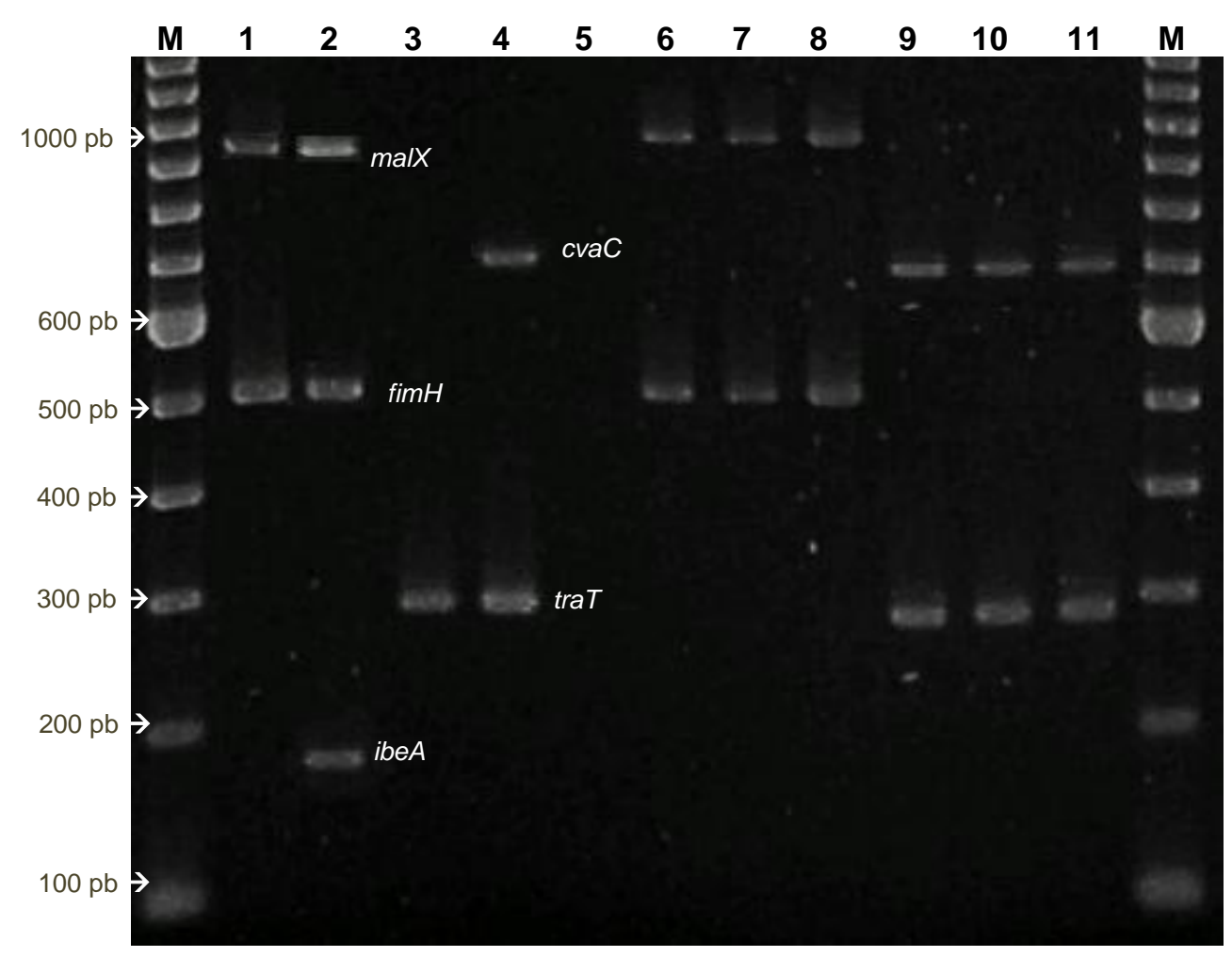

Figura 3. Produtos de PCR Multiplex para detecção dos genes ibe $A$ (171 pb), fimH (508 pb), malX $(925 \mathrm{pb})$ e traT (290 pb), colV (679 pb). Canaletas M, marcador de peso molecular 100 $\mathrm{pb}^{12}$; canaleta 1. amostra-padrão JJ079, positiva para os genes fimH e malX; canaleta 2. amostra-padrão BUTI 3-1-4, positiva para os genes ibeA, fimH e malX; canaleta 3. amostra-padrão JJ079, positiva para o gene $c v a C$; canaleta 4. amostra-padrão BUTI 1-7-6, positiva para os genes traT e $c v a C$, canaleta 5 . amostra-padrão JJ055, negativa para todos os genes; canaleta 6. amostra 50a; canaleta 7. amostra 50b; canaleta 8. amostra 50c, todas positivas para os genes $\mathrm{fimH}$ e malX; canaleta 9. amostra 50a; canaleta 10. amostra 50b; canaleta 11. amostra 50c, todas positivas para os genes traT e cvaC.

12100 bp DNA Ladder, Invitrogen Corporation, Carlsbad, EUA 


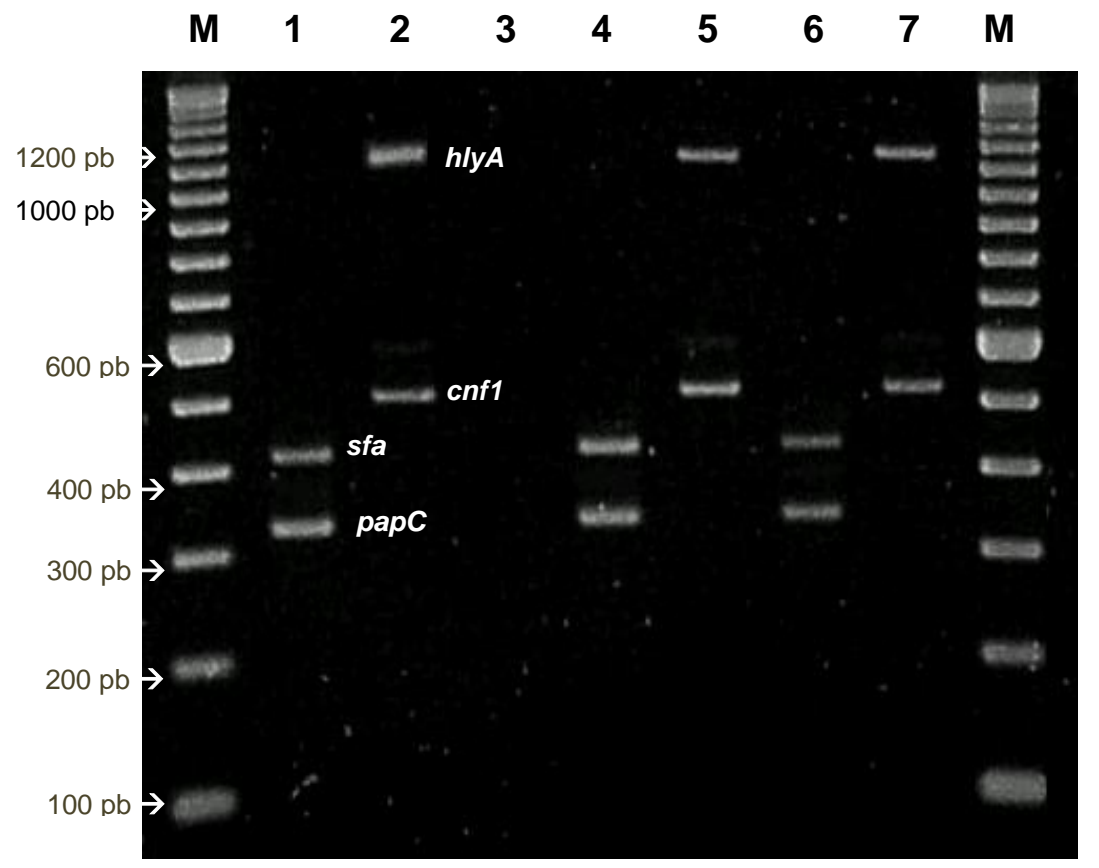

Figura 4. Produtos de PCR Multiplex para detecção dos genes genes papC (328 pb), sfa (410 pb), cnf1 (498 pb) e hly (1177 pb). Canaletas M, marcador de peso molecular $100 \mathrm{pb}$; canaleta 1. amostra-padrão $\mathrm{C} 7$, positiva para os $p a p C$ e sfa; canaleta 2. amostra -padrão $\mathrm{C} 7$, positiva para os genes cnf1 e hlyA; canaleta 3. Amostra-padrão K12c600, negativa para todos os genes; canaletas 4 e 5. amostra 70; canaletas 6 e 7. amostra 77, ambas com o mesmo perfil de virulência para os genes testados (papC+, sfa+, cnf1, hlyA+) 
Os resultados das amplificações para os genes chuA e yjaA, além do fragmento TspE4.C2, apresentados na Tabela 6, foram interpretados segundo a árvore de decisão dicotômica (Figura 2) possibilitando o agrupamento das 45 cepas entre os quatro principais grupos de $E$. coli da seguinte forma: 4,5\% (2/45) no grupo A, $15,5 \%$ (7/45) no grupo B1, 62\% (28/45) no grupo B2 e 18\% (8/45) no grupo D. As cepas isoladas de gatos concentraram-se no grupo B2 $(8 / 9=89 \%)$, com apenas uma amostra (11\%) classificada como pertencente ao grupo D. Por outro lado, os 36 isolados caninos distribuíram-se entre os quatro grupos, com duas amostras no grupo A (5,5\%), sete (19,5\%) amostras em B1, 20 (55,5\%) cepas agrupadas em B2 e as sete restantes $(19,5 \%)$ no grupo $D$.

Observou-se no agrupamento das 45 cepas entre os quatro principais grupos filogenéticos de $E$. coli que as amostras com maior número de FVs pertenciam ao grupo B2. Os marcadores para a fímbria $P$, toxinas, invasina (IbeA) e para a $\mathrm{PAl}_{\mathrm{CFT} 073}$ restringiram-se aos grupos $\mathrm{B} 2$ e $\mathrm{D}$, assim como os sorogrupos $\mathrm{O} 2$, O4, O6, O18, O21, O25, 083 e 0153 (Tabela 6). Todas as amostras pertencentes ao grupo B2 apresentavam marcador para o sideróforo yersiniabactina e para a ilha de patogenecidade pesquisada, com exceção da amostra 74, negativa para o gene malX. O marcador para a fímbria $S$ também foi encontrado apenas nas amostras pertencentes ao grupo B2.

Houve uma correlação de $100 \%$ entre as 12 amostras (11, 29, 36, 40, 52, $55,57,59,70,77,80$ e 87 ) positivas para a o gene hlyA e a expressão da $\alpha$ hemolisina. Somente a amostra 97 apresentou zona de hemólise após incubação por 24 horas, caracterizando a presença da enterohemolisina.

No teste de hemaglutinação, utilizado para verificação da expressão das fímbrias do tipo 1 e $\mathrm{P}$, das 45 cepas não foi detectada a hemaglutinação tanto na ausência como na presença da D-manose em 7\% (3/45) destas (Tabela 7). Embora todos os isolados estudados apresentassem a seqüência para o gene $\mathrm{fimH}$, a expressão desta fímbria não foi detectada nas amostras de $n^{\circ} 20,58$ e 83 .

Excluindo-se as cepas sem aglutinação, nas outras 42 cepas, 60\% (25/42) apresentaram hemaglutinação somente na ausência da D-manose, com escore de $1+$ a 4+. Todas as cepas da espécie felina (9/9) apresentaram hemaglutinação, com 
escore de 1+ a 3+. As da espécie canina, 33 das 36 (92\%) apresentaram hemaglutinação, com escore de $1+$ a $4+$.

Nos 17 isolados restantes, observou-se a hemaglutinação na presença de Dmanose, mas com escore mais baixos, variando de 1+ a no máximo 2+, correspondendo a 67\% (6/9) das amostras felinas e 30,5\% (11/36) das caninas. Destas, somente sete cepas (50a, 50b, 50c, 73, 59, 87 e 42) apresentaram escore igual à hemaglutinação sem este açúcar, sendo classificadas como MRHA. 
Tabela 7. Amostras isoladas de gatos e cães com ITU, em relação ao grupamento filogenético, sorotipo, presença de FV que codificam a produção de adesinas e a expressão destas através do teste de hemaglutinação.

\begin{tabular}{|c|c|c|c|c|c|c|c|c|c|c|c|c|}
\hline \multirow{2}{*}{ Espécie } & \multirow{2}{*}{$\begin{array}{c}\text { Grupo } \\
\text { Filogenético }\end{array}$} & \multirow{2}{*}{ Amostra } & \multirow{2}{*}{ Sorotipo } & \multicolumn{6}{|c|}{ Adesina } & \multicolumn{3}{|c|}{ Hemaglutinação } \\
\hline & & & & fimH & papc & papEF & sfa & afa & iha & sem manose & com manose & classificação' \\
\hline \multirow{9}{*}{$\frac{\nwarrow}{\underline{z}}$} & \multirow{8}{*}{ B2 } & $50 a$ & $\mathrm{O} 2: \mathrm{H} 4$ & + & + & + & & & & $2+$ & $2+$ & MRHA \\
\hline & & $50 \mathrm{~b}$ & $\mathrm{O}: \mathrm{H} 8$ & + & + & + & & & & $2+$ & $2+$ & MRHA \\
\hline & & $50 \mathrm{c}$ & $\mathrm{O} 2: \mathrm{H}^{-}$ & + & + & + & & & & $2+$ & $2+$ & MRHA \\
\hline & & 57 & $\mathrm{O}: \mathrm{H}-$ & + & + & + & + & & & $3+$ & $2+$ & MSHA \\
\hline & & 36 & $\mathrm{O6}: \mathrm{H} 1$ & + & & & + & & & $3+$ & 0 & MSHA \\
\hline & & 73 & O18:H- & + & + & + & & & + & $1+$ & $1+$ & MRHA \\
\hline & & 52 & $\mathrm{O} 21: \mathrm{H} 14$ & + & + & + & + & & & $2+$ & $1+$ & MSHA \\
\hline & & 61 & ONT:HNT & + & & & & & & $2+$ & 0 & MSHA \\
\hline & D & 99 & $\mathrm{O} 15: \mathrm{H} 45$ & + & & & & & & $3+$ & 0 & MSHA \\
\hline \multirow{9}{*}{ 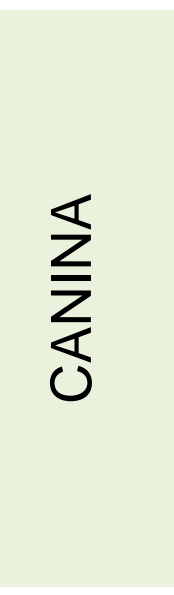 } & \multirow{5}{*}{$A$} & 64 & ONT:H- & + & & & & & & $1+$ & 0 & MSHA \\
\hline & & 83 & $\mathrm{O} 11: \mathrm{H} 4$ & + & & & & & & 0 & 0 & $\mathrm{~N}$ \\
\hline & & 82 & $\mathrm{O} 20: \mathrm{H} 12$ & + & & & & & & $1+$ & 0 & MSHA \\
\hline & & 56 & O23:H16 & + & & & & & & $3+$ & 0 & MSHA \\
\hline & & 58 & ONT:H8 & + & & & & & & 0 & 0 & $\mathrm{~N}$ \\
\hline & \multirow[t]{4}{*}{ B1 } & 53 & ONT:H21 & + & & & & & & $3+$ & 0 & MSHA \\
\hline & & 45 & ONT:H23 & + & & & & & & $1+$ & 0 & MSHA \\
\hline & & 46 & ONT:H45 & + & & & & & & $1+$ & 0 & MSHA \\
\hline & & 75 & OR:H16 & + & & & & & & $3+$ & 0 & MSHA \\
\hline
\end{tabular}


Tabela 7 (continuação)

\begin{tabular}{|c|c|c|c|c|c|c|c|c|c|c|c|c|}
\hline \multirow{2}{*}{ Espécie } & \multirow{2}{*}{$\begin{array}{c}\text { Grupo } \\
\text { Filogenético }\end{array}$} & \multirow{2}{*}{ Amostra } & \multirow{2}{*}{ Sorotipo } & \multicolumn{6}{|c|}{ Adesina } & \multicolumn{3}{|c|}{ Hemaglutinação } \\
\hline & & & & $\mathrm{fimH}$ & papC & papEF & sfa & afa & iha & sem manose & com manose & classificação $^{1}$ \\
\hline \multirow{20}{*}{$\frac{\mathbb{Z}}{\sum}$} & \multirow{20}{*}{$\mathrm{B2}$} & 29 & $\mathrm{O} 2: \mathrm{H} 6$ & + & & & + & & & $3+$ & 0 & MSHA \\
\hline & & 84 & $\mathrm{O} 2: \mathrm{H} 31$ & + & & & & & & $1+$ & 0 & MSHA \\
\hline & & 38 & $\mathrm{O} 4: \mathrm{H}-$ & + & + & + & + & & & $3+$ & $1+$ & MSHA \\
\hline & & 9 & $\mathrm{O}: \mathrm{H}-$ & + & + & + & + & & & $3+$ & 0 & MSHA \\
\hline & & 40 & $\mathrm{O} 6: \mathrm{H}-$ & + & + & + & + & & & $2+$ & $1+$ & MSHA \\
\hline & & 59 & $\mathrm{O} 6: \mathrm{H}-$ & + & + & + & + & & & $2+$ & $2+$ & MRHA \\
\hline & & $70^{a}$ & $\mathrm{O} 6: \mathrm{H}-$ & + & + & + & + & & & $2+$ & $1+$ & MSHA \\
\hline & & 80 & $\mathrm{O} 6: \mathrm{H}-$ & + & + & + & + & & & $2+$ & 0 & MSHA \\
\hline & & $77^{a}$ & $\mathrm{O} 6: \mathrm{H} 31$ & + & + & + & + & & & $2+$ & $1+$ & MSHA \\
\hline & & 93 & O6:H31 & + & + & + & & & & $3+$ & $1+$ & MSHA \\
\hline & & 55 & $\mathrm{O} 21: \mathrm{H} 14$ & + & + & + & + & & & $4+$ & $1+$ & MSHA \\
\hline & & 11 & O25:H11 & + & + & + & + & & + & $4+$ & 0 & MSHA \\
\hline & & 71 & O25:HNT & + & & & & & & $2+$ & 0 & MSHA \\
\hline & & 41 & О83:Н31 & + & & & & & & $2+$ & 0 & MSHA \\
\hline & & 60 & O83:H31 & + & & & & & & $3+$ & 0 & MSHA \\
\hline & & 95 & ONT:H4 & + & & & + & & & $2+$ & 0 & MSHA \\
\hline & & 89 & ONT:H45 & + & & & & & & $2+$ & 0 & MSHA \\
\hline & & 90 & ONT:H45 & + & & & & & & $3+$ & 0 & MSHA \\
\hline & & 74 & ONT:HNT & + & & & & & & $3+$ & $0+$ & MSHA \\
\hline & & 87 & OR:H? & + & + & + & + & & & $1+$ & $1+$ & MRHA \\
\hline
\end{tabular}


Tabela 7 (continuação)

\begin{tabular}{|c|c|c|c|c|c|c|c|c|c|c|c|c|}
\hline \multirow{2}{*}{ Espécie } & \multirow{2}{*}{$\begin{array}{c}\text { Grupo } \\
\text { Filogenético }\end{array}$} & \multirow{2}{*}{ Amostra } & \multirow{2}{*}{ Sorotipo } & \multicolumn{6}{|c|}{ Adesina } & \multicolumn{3}{|c|}{ Hemaglutinação } \\
\hline & & & & fimH & papC & papEF & sfa & afa & iha & sem manose & com manose & classificação $^{1}$ \\
\hline \multirow{7}{*}{ 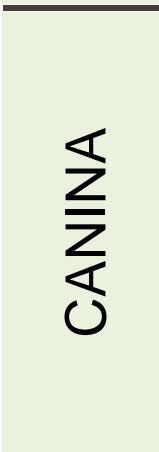 } & \multirow{7}{*}{$\mathrm{D}$} & $23^{b}$ & O2:HNT & \pm & + & & & & & $2+$ & $1+$ & MSHA \\
\hline & & $42^{b}$ & O2:HNT & + & + & & & & & $1+$ & $1+$ & MRHA \\
\hline & & 81 & O153:H34 & + & & & & & & $1+$ & 0 & MSHA \\
\hline & & 20 & ONT:H4 & + & + & + & & & & 0 & 0 & $\mathrm{~N}$ \\
\hline & & 15 & ONT:H6 & + & & & & & & $4+$ & 0 & MSHA \\
\hline & & $49^{b}$ & ONT:HNT & + & + & + & & & & $2+$ & $1+$ & MSHA \\
\hline & & 97 & OR:H- & + & & & & & & $4+$ & 0 & MSHA \\
\hline
\end{tabular}

Legenda:

1. MSHA - hemaglutinação manose sensível; MRHA - hemaglutinação manose resistente

(a) Amostras colhidas do mesmo animal, nas seguintes datas: 04/03/2006 (70); 24/03/2006 (77)

(b) Amostras colhidas do mesmo animal, nas seguintes datas: 12/08/2005 (23); 23/09/2005 (42); 10/10/2005 (49) 


\section{Discussäa}

Desde a sua descoberta, no final do século XIX pelo pediatra Theodor Escherich, a Escherichia coli tornou-se o organismo mais bem estudado, tanto pelo seu papel como "modelo" em estudos de biologia molecular, mas também por sua versatilidade como patógeno, ocasionando infecções nos mais variados sítios anatômicos (HACKER e BLUM-OEHLER, 2007).

As infecções do trato urinário estão entre as mais freqüentes infecções extra-intestinais tanto em animais como no homem. A taxa de morbidade entre cães é de 10 a 14\%; já em felinos as infecções possuem uma menor freqüência, associadas geralmente a animais idosos (BARTGES, 2004; DOWLING, 1996; JOHNSON et al., 2003; LULICH e OSBORNE, 2004). No presente estudo, das 72 amostras colhidas de animais com ITU, foram isoladas $43(60 \%)$ cepas de E. coli, corroborando com diversos estudos, que apontam este microrganismo como o principal agente destas infecções (KURAZONO et al., 2003; WOOLEY e BLUE, 1976; YURI et al., 2000).

Para a caracterização de E. coli isoladas neste estudo optou-se, inicialmente, pela metodologia descrita por Yamamoto e colaboradores (1995), metodologia esta aplicada em diversos estudos epidemiológicos, com a pesquisa de sete genes que codificam FV (papC, papEF, sfa, afal, hlyA, iucD, cnf1). A inclusão de mais sete genes ( $f i m H$, iha, ibeA, fyuA, traT, $c v a C, m a l X)$, relacionados não apenas a urovirulência, como também a outras infecções extra-intestinais (JOHNSON e STELL, 2000), permitiu uma melhor caracterização das amostras, uma vez que $35,5 \%$ (16/45) das amostras não apresentaram nenhum dos primeiros sete genes pesquisados, subestimando-se o potencial de virulência das mesmas.

Os isolados provenientes de um mesmo animal, colhidos em diferentes intervalos de tempo, mostraram duas situações distintas. No caso das duas primeiras amostras colhidas de um cão da raça Beagle (23 e 42) e dos isolados de outro cão da raça Bichon-Frisé (70 e 77) observou-se possivelmente uma infecção recorrente, ou seja, a persistência da mesma bactéria ocasionando a ITU. Já a 
segunda situação é sugestiva de uma reinfecção, uma vez que o último isolado (49) do Beagle apresentou um perfil genotípico diferente dos isolados anteriores (23 e 42). Esta situação pode ter ocorrido devido a uma nova infecção, ocasionada por diferente cepa de E. coli ou, pelo mesmo isolado que adquiriu novos FV. Casos de infecção recorrente e reinfecção ocasionados por $E$. coli com resistência a antibióticos são descritos na literatura (BARTGES, 2004; POLZIN, 1994; SEGUIN et al., 2003).

Embora em três colheitas, 80, 89 e 95, a quantificação bacteriana indicou uma suspeita de ITU, segundo a classificação preconizada por Polzin (1994), as cepas de $E$. coli isoladas nestes casos apresentaram oito, três e seis marcadores de virulência, respectivamente, todas agrupadas no grupo B2, grupo este relacionado às ExPEC (JOHNSON et al., 2001a, 2006).

Dentre os sorogrupos relatados por diversos pesquisadores como os mais freqüentemente relacionados às infecções urogenitais de cães, gatos e humanos, além de meningite e septicemia no homem encontram-se, O2, O4, O6, O11, 018, O25, O75 e O102 (GRINDLAY et al., 1973; JOHNSON, 1991, 2001a, 2001b; LOW et al., 1988; WESTERLUNG et al., 1987; WILKINSON, 1974; WILSON et al., 1988; YURI et al.,1998b), vários destes identificados neste estudo.

Johnson e colaboradores (2008) em um estudo comparativo de E. coli do sorogrupo $\mathrm{O} 6$ isoladas de humanos, cães e gatos, demonstraram que tais isolados derivaram do mesmo grupo filogenético (B2). Estas amostras apresentaram genótipos de virulência idênticos, além de identidade clonal, reforçando a hipótese do potencial zoonótico destes clones e possibilidade de transmissão entre as espécies, como em humanos e seus animais de companhia (JOHNSON et al., 2006; MURRAY, et al. 2004). Os dados obtidos no presente estudo corroboram com a hipótese destes autores, com nove isolados $(57,36,9,40,59,70,80,77$ e 93) do sorogrupo $\mathrm{O} 6$ também pertencentes ao grupo B2, apresentando de cinco a nove marcadores de virulência. Todos estes isolados possuíam marcadores para toxinas, exceto a amostra 9. Vale ressaltar que o sorotipo $\mathrm{O} 6: \mathrm{H} 1$, encontrado na amostra 36 e O6:H31, nas amostras 77 e 93, estão entre os mais relacionados a ITU em humanos, cães e gatos (CHERIFI et al., 1991; JOHNSON e STELL, 2000; JOHNSON et al., 2001a; ORSKOV e ORSKOV, 1983; YURI et al., 1998b). 
$\mathrm{Na}$ amostra protótipo de UPEC, CFT073 (O6:K2:H:1), a ilha de patogenecidade associada ao operon pap, localizada em phe $V$, também codifica a produção de hemolisina e alberga os genes para aerobactina (WELCH et al., 2002), semelhante perfil foi encontrado na amostra 57 , embora sem a identificação do antígeno $\mathrm{H}$, substanciando o potencial zoonótico das amostras de origem animal.

Embora presente tanto em amostras comensais como em patogênicas, o operon fim apresenta diferenças em sua expressão, na especificidade do receptor com a adesina fimH ou ambos. A freqüência deste é maior em pacientes com cistite e o epitélio da bexiga parece induzir a expressão do operon fim (JOHNSON e RUSSO, 2002). Todas as amostras testadas foram positivas para o gene $\mathrm{fimH}$, utilizado como marcador de virulência para esta fímbria. Resultados semelhantes foram obtidos em amostras humanas (JOHNSON e STELL 2000), caninas (JOHNSON et al., 2003) e felinas (FREITAG et al., 2005). Em um estudo sobre a atividade da amostra de UPEC CFT073 (O6:K2:H11) durante a ITU os autores demonstraram que o gene fimA apresentava a quarta maior taxa de expressão, atrás somente de três genes relacionados à tradução (fator de enlogamento da cadeia de proteínas, proteínas formadoras das subunidades $30 \mathrm{~S}$ e $50 \mathrm{~S}$ do ribossomo); dentre os 12 clusters fimbriais presentes em CFT073, o da fímbria do tipo 1 era preferencialmente ativado (SNYDER et al., 2004), o que explicaria a sua alta freqüência em isolados provenientes de ITU, como as deste estudo.

As fímbrias $\mathrm{S}$, codificadas pelos genes contidos no cluster sfa são usualmente associadas a processos generalizados no homem como sepsis e meningites (JOHNSON, 1991; MIYAZAKI et al., 2002). Este genótipo esteve presente em $33 \%$ das amostras de ExPEC deste estudo, dados próximos ao verificado por Johnson e colaboradores (2003) em estudo que verificou a presença deste gene em $39 \%$ das amostras de cães estudadas.

Outra fímbria também associada a processos sépticos é a fímbria $\mathrm{P}$, codificada pelo cluster gênico pap. No homem esta fímbria está principalmente associada a processos de pielonefrite $(70 \%)$, sendo menos freqüente em pacientes com cistite $(36 \%)$, bacterúria assintomática $(24 \%)$ e portadores fecais (19\%). Além disso, $71 \%$ dos isolados com este genótipo foram associados a bacteremia decorrente de ITU (JOHNSON, 1991). Em cães e gatos também foram detectados 
altos percentuais (ao redor de 50\%) de amostras positivas para este fator de virulência em animais com ITU (LOW et al., 1988; YURI et al., 1998a), dados compatíveis com os obtidos no presente estudo, onde se verificou a presença deste marcador em $42 \%$ dos isolados pesquisados.

As adesinas Afa têm sido associadas principalmente à cistite, estando presente em 30-50\% dos pacientes humanos com esta afecção (JOHNSON, 1991). Amostras com este marcador de virulência não foram detectadas neste trabalho de pesquisa, dados compatíveis com os demonstrados por Yuri et al. (1998a), que verificaram baixos percentuais (4\% em cães e $8 \%$ em gatos). Em condições de hibridização de alta estringência ou em PCR específicas para afa, cujas seqüências analisadas eram específicas para o operon afa de amostras humanas, as amostras afa animais foram negativas, sugerindo que os operons para este gene são estruturalmente diferentes entre animais e humanos (LE BOUGUÉNEC e BERTIN, 1999).

O ferro é essencial para o crescimento bacteriano. Hagan e Mobley (2007) sugeriram que as células epiteliais da bexiga seqüestram o ferro, tornando o ambiente limitado para a bactéria, o que levaria a expressão de proteínas de membrana externa com a função de receptar o ferro. Primeiramente descrita em $E$. coli $0157: H 7$, a lha é uma proteína de membrana externa com função de adesina e receptadora de sideróforos (LÉVEILLÉ et al., 2006; TARR et al., 2000;). Os resultados obtidos nos isolados pesquisados indicaram uma menor incidência deste gene nas amostras animais (4\%). No entanto, se considerarmos a freqüência deste gene individualmente em cada espécie, a porcentagem de amostras iha+ em felinos foi de $11 \%$ (1/9), ao passo que na espécie canina, o percentual foi mais baixo, correspondendo a $3 \%(1 / 36)$ dos isolados desta espécie. A freqüência deste gene nas amostras felinas foi mais próxima ao observado nas amostras humanas, uma vez que esta adesina é encontrada em uma freqüência de 37 a 55\% em isolados humanos de ITU (BAUER et al., 2002; JOHNSON et al., 2000, 2005).

Neste estudo verificou-se a freqüência de dois sideróforos: yersiniabactina, identificado originalmente em cepas de Yersina spp. (SCHUBERT et al., 1998) e aerobactina, que tem sido mais comumente detectado em pacientes humanos com pielonefrite (JOHNSON, 1991). Snyder et al. (2004) demonstraram que sistemas de 
aquisição e assimilação de ferro apresentaram uma maior expressão durante a infecção, chegando a uma taxa duas vezes maior do que a apresentada in vitro.

O gene fyuA, que codifica o receptor para yersiniabactina FyuA, apresentouse em $80 \%$ dos isolados, dados compatíveis com os achados de Johnson et al. (2001a) em cães e Freitag et al. em gatos (2005).

Como marcador para aerobactina utilizou-se o gene iucD ("iron uptake chelate"). Os $22 \%$ de amostras com este marcador foram superiores ao detectado por Yuri et al. (1998a) em cães e semelhantes ao de gatos. A localização de determinantes para aerobactina foi descrita tanto em cromossomo como em plasmídios; $62,5 \%$ das amostras positivas para iucD também apresentavam o gene $c v a C$, indicando a provável localização plasmidial do gene, conforme previamente descrito na literatura (FERNANDEZ-BEROS et al., 1990; JOHNSON et al., 1988).

Em 13\% das amostras nenhum dos dois sideróforos foi identificado. Devido à importância do ferro no crescimento bacteriano e da escassez deste livre no organismo, estes isolados capazes de ocasionar infecções extra-intestinais possivelmente apresentem outro sistema de aquisição de ferro não pesquisado.

O gene cvaC, que está inserido no plasmídio ColV e codifica a produção de colicina V (GILSON et al., 1987), foi utilizado como marcador plasmidial. Nas amostras pesquisadas, o gene cvaC foi positivo em $20 \%$, das quais $86 \%$ também apresentavam o gene traT e $71 \%$ o iucD, indicando a possível associação destes genes no plasmídio ColV, como já demonstrado por Fernandez-Beros e colaboradores (1990).

TraT é uma lipoproteína de membrana externa, codificada pelo gene traT, que aumenta a resistência bacteriana à ação lítica do complemento, conferindo resistência ao soro (SUKUPOLVI e O'CONNOR, 1990). Esse gene foi identificado em $49 \%$ das amostras, mas somente $28 \%$ apresentavam o plasmídio ColV. Como descrito por Johnson (1991) a presença deste gene já foi descrita em outros F-like plasmídios, como R6-5 e R100, indicando a possibilidade de que estes isolados possuam o gene traT em outros plasmídios não pesquisados.

Uma das toxinas produzidas por cepas de ExPEC é o Fator Citotóxico Necrotizante 1 (CNF-1). Este gene foi detectado em $32 \%$ das amostras deste 
estudo, percentual mais baixo que o verificado em cães e gatos doentes $(52 \%$ e $64 \%$, respectivamente) por Yuri et al.(1998a).

Vários estudos têm demonstrado que a $\alpha$-hemolisina é um importante fator de virulência em amostras isoladas de infecção urinária em cães, gatos e humanos (DRAZENOVICH, 2004; LOW et al., 1988; WILSON et al., 1988; YURI et al., 1998a). Amostras produtoras de $\alpha$-hemolisina induzem a formação de pequenas aberturas, rompendo a integridade do epitélio ("focal leaks"), possibilitando a translocação das bactérias do epitélio intestinal para outros sítios, uma das possíveis portas de entrada para as infecções extra-intestinais em pacientes imunocomprometidos (TROEGER et al., 2007). Somente 28\% das amostras estudadas presentemente, mostraram positividade para esse gene. Houve, entretanto, grande correlação entre a presença de hlyA e cnf1, uma vez que $100 \%$ das amostras que apresentaram o primeiro, demonstraram também o segundo, fenômeno descrito por outros autores (BOWER et al., 2005; DE RYCKE et al., 1997, 1999; SALYERS e WHITT, 2002; YURI et al., 1998a). A expressão desta toxina foi observada em ensaio realizado em ágar sangue, em todas as amostras positivas na PCR para o gene hlyA, confirmando o potencial patogênico destas amostras, quanto à capacidade hemolítica.

A capacidade de cepas de E. coli de invadir as células cerebrais, ocasionando a meningite neonatal foi verificada por Huang e colaboradores (1995), que identificaram o gene $i b e A$ como um dos responsáveis por esse fenômeno. $A$ invasão ocorre primeiramente com a ligação das bactérias às células endoteliais da microcirculação cerebral. Estas passam então a invadi-las pelo mecanismo "zíperlike", sem que haja o rompimento das junções intercelulares (XIE et al., 2004). Esta invasina apresentou-se em $30 \%$ dos isolados de ITU deste estudo. Tal fato reforça a idéia de que uma parcela significativa de amostras de E. coli envolvidas em ITU animal tem potencial para ocasionar quadros de maior gravidade, a semelhança do que é descrito em humanos, onde os isolados com este genótipo ocasionaram meningite neonatal, tendo como porta de entrada as vias urinárias (BONACORSI e BINGEN, 2005).

Os resultados obtidos neste estudo corroboram com a proposta de Russo e Johnson (2000) para a utilização do acrônimo ExPEC, uma vez que os isolados provenientes de ITU apresentaram marcadores de virulência e sorotipos 
relacionados a quadros de sépsis e meningite neonatal, demonstrado a plasticidade destas bactérias, que através da aquisição de diferentes genes de virulência, apresentam uma vantagem competitiva, possibilitando a colonização de diversos sítios anatômicos (JOHNSON e RUSSO, 2002)

A ocorrência de mais de um fator de virulência, em regiões cromossômicas das amostras patogênicas foi verificada na década de 80 por Goebel e colaboradores, sendo posteriormente denominadas como Ilhas de Patogenicidade (PAls) (HACKER et al., 1997). Em amostras-padrão de UPEC foram identificadas cinco ilhas na amostra 536 (PAI I $I_{536}$ a PAI $V_{536}$ ), três em J96 (PAI I I96, PAI II $I_{\text {J96 }}$ e

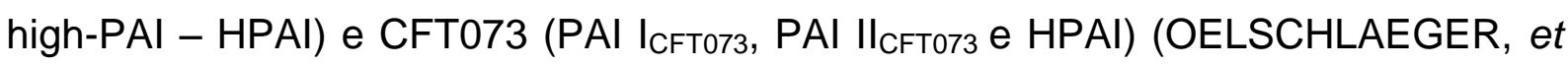
al., 2002; SCHMIDT e HENSEL, 2004).

A razão deste agrupamento de genes poderia ser explicada pela eficácia da transmissão dos genes contidos em PAls ser maior quando em conjunto do que espalhados, isoladamente, pelo genoma (JOHNSON e RUSSO, 2002). O gene

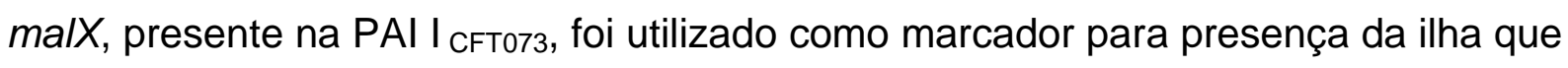
contém os operons para pap e hlyA (JOHNSON e STELL, 2000; KAO et al., 1997). O marcador para PAI esteve presente em $67 \%$ dos isolados. Com exceção da amostra 20 , todas as amostras que apresentaram o gene pap também foram positivas para malX. Da mesma forma, o gene hlyA apresentou uma correlação de $100 \%$ com a ilha. No entanto, a associação dos três genes $\left(\operatorname{malX}^{+}\right.$pap $\left.h l y A^{+}\right)$foi de apenas 36\% $(10 / 28)$.

A capacidade de adesão pode ser determinada pela aglutinação, um teste simples no qual as amostras de $E$. coli e eritrócitos de diferentes espécies são misturados em lâminas ou em placas de microtitulação, tanto na presença como na ausência de D-manose (HACKER, 1992). A maioria das adesinas expressas por cepas de E. coli exibe uma variação de fase, ou seja, mesmo que a amostra possua vários clusters para diferentes fímbrias, a expressão de cada uma delas não ocorre simultaneamente e varia de acordo com o ambiente. Esta comunicação ("cross-talk") parece evitar a estimulação imunológica excessiva do hospedeiro (HOLDEN, 2006). Tem sido demonstrado um mecanismo relacionado à expressão das fímbrias do tipo 1 e P que, aparentemente, evidencia este fenômeno. Quando o cluster pap é acionado, a produção de $\mathrm{PapB}$ atuaria tanto como regulador da expressão da 
fímbria $\mathrm{P}$, como também apresentaria ação sobre o locus fim, prevenindo a expressão da fímbria do tipo 1 (HOLDEN et al., 2001; XIA et al., 2000).

Observou-se tal situação no teste de hemaglutinação, principalmente nas amostras positivas para o operon pap. Dos isolados de felinos, seis cepas (50a, 50b, 50c, 57, 73 e 52) apresentaram marcadores para a fímbria P. Em quatro casos, cepas 50a, 50b, 50c e 73, o escore de aglutinação tanto na presença como na ausência de D-manose foi o mesmo, indicando apenas a transcrição do cluster de genes pap. Embora com variação de apenas um ponto, as cepas 52 e 57 apresentaram valores menores de hemaglutinação na presença do açúcar, 1+ e 2+, respectivamente, do que na sua ausência (2+ e 3+). Mesmo assim, os resultados são indicativos de que a presença da fímbria $P$ seria a responsável pela maior atividade hemaglutinante, com parcial repressão da fímbria do tipo 1 .

Nos isolados caninos, a situação repetiu-se em oito das 15 (53\%) cepas positivas para o operon pap $(40,59,70,77,87,23,42$ e 49), com escore para hemaglutinação na presença da D-manose igual ou com apenas 1 ponto de diferença em relação aos valores obtidos na ausência do açúcar.

Em um estudo sobre o grau de severidade das ITU ocasionadas pelas amostras de ExPEC, Hagberg e colaboradores (1981) observaram uma grande correlação entre a virulência e a MRHA de eritrócitos humanos, com aproximadamente $77 \%$ de isolados de pacientes com pielonefrite aguda expressando tal padrão de hemaglutinação, ilustrando a capacidade da bactéria, que expressa a fímbria $\mathrm{P}$, de aderir-se às células uroepiteliais humanas.

Em 40\% das cepas (38, 9, 80, 93, 55 e 11), a hemaglutinação na ausência do açúcar foi superior, indicativo da transcrição do operon fim. Notou-se ainda que naquelas cepas em que só foi identificado o marcador para a fímbria do tipo 1 , os escores de hemaglutinação foram maiores. Uma possível explicação para tal fenômeno seria que, sem a repressão exercida pela $\mathrm{PapB}$, o operon fim permaneceria "ligado", transcrevendo a fímbria do tipo 1, resultando em uma maior atividade hemaglutinante, como descrito acima.

No isolado de $\mathrm{n}^{\circ} \mathbf{2 0}$, embora sendo detectados os marcadores para a fímbria do tipo 1 e $P$, não foi observada nenhuma atividade hemaglutinante, indicando a 
ausência de expressão destas duas fímbrias in vitro. O mesmo ocorreu com a amostra 83 que apresentava apenas a fímbria do tipo 1. Porém, os dados clínicos e laboratoriais foram condizentes com infecção urinária bacteriana, sendo que a $E$. coli foi o único microrganismo isolado. Esses dados indicam que tais cepas eram os agentes destas ITU. Ou seja, os marcadores encontrados neste isolado possivelmente estariam expressos in vivo. É possível que a utilização de hemácias de outras espécies animais, assim como a semeadura da bactéria em diferentes meios de cultura poderiam levar à expressão das fímbrias e a obtenção de um padrão diferente do que foi apresentado neste estudo.

Ao contrário das amostras comensais e patogênicas intestinais, as ExPEC são derivadas predominantemente do grupo filogenético $\mathrm{B} 2$, com algumas cepas provindas do grupo D. Estes clones específicos são caracterizados por determinados sorotipos, e apresentam FV que permitem a estas amostras colonizar a mucosa do hospedeiro, evitar ou subverter os mecanismos de defesa local ou sistêmico, adquirir nutrientes essenciais, invadir as células do tecido hospedeiro e estimular a resposta inflamatória (JOHNSON e RUSSO, 2002).

Neste estudo, os marcadores de virulência pesquisados se distribuíram aleatoriamente entre os diversos sorogrupos encontrados. Com a determinação do grupamento filogenético foi possível identificar a segregação de marcadores virulência a certas linhagens. Das amostras de origem felina, 8 dos 9 isolados foram agrupados em B2. Todos os isolados com marcadores para as fímbrias $\mathrm{P}$ e $\mathrm{S}$, além das toxinas, foram agrupados em B2 ou D. Como já descrito na literatura, a presença e a expressão das fímbrias $P$ e $S$, além da $\alpha$-hemolisina é mais comum entre as amostras pertencentes ao grupo filogenético $B 2$ e $D$, enquanto outros $F V$, como o operon para afa, aerobactina e traT, encontram-se amplamente distribuídos entre os grupos (BINGEN-BIDOIS et al., 2002; JOHNSON et al. 1991, 2001a; JOHNSON e RUSSO, 2005).

Estes resultados sugerem que as ExPEC isoladas de cães e gatos apresentam características genotípicas e sorogrupos semelhantes às encontradas em infecções humanas. Estes achados são sugestivos de que tais isolados podem estar relacionados a outras doenças de cães e gatos, além das ITU, uma vez que o diagnóstico e acompanhamento de doenças graves, como meningites e septicemias, 
ocorre menos freqüentemente em medicina veterinária. No mais, as semelhanças quanto aos sorotipos e genes de virulência das ExPEC de origem animal com os isolados humanos permitem a especulação da possibilidade de infecções cruzadas entre ambos, humanos e animais de companhia, como o referido por outros autores (JOHNSON et al., 2001a; 2001b; JOHNSON e CLABOTS, 2006; LOW et al., 1988; WHITTAM et al., 1989; YURI et al., 1998; 1999). 
Escherichia coli foi o microrganismo mais comumente associado às ITU em animais de companhia.

Observou-se através de colheitas repetidas de dois animais a ocorrência de persistência de infecção em um caso e, um processo de reinfecção por cepa diferente em outro, a despeito do tratamento com antibióticos.

Na grande maioria, as infecções por E. coli ocorreram, provavelmente, devido à multiplicação de um único clone patogênico, uma vez que as três colônias isoladas de cada indivíduo apresentaram perfis de virulência e sorotipos idênticos.

Os isolados de E. coli apresentaram sorogrupos relacionados às ITU e outras infecções extra-intestinais, sendo os mais prevalentes os sorogrupos O6 e O2.

A maioria dos isolados pertencentes ao sorogrupo 06 apresentaram marcadores para toxinas e fímbrias $\mathrm{P}$ e $\mathrm{S}$, assim como ocorre em isolados humanos de ExPEC.

Todas as cepas estudadas apresentaram pelo menos um dos marcadores de virulência pesquisados, sendo que em $47 \%$ foram encontrados acima de seis marcadores de patogenecidade.

Todas as amostras felinas foram incluídas nos grupos B2 e D, assim como 27 $(60 \%)$ das amostras caninas, à semelhança do que ocorre com amostras isoladas de vários sítios extra-intestinais humanos e animais.

^ O presente estudo incluiu uma ampla pesquisa de fatores de virulência, em amostras de origem animal, pesquisa esta geralmente realizada apenas em amostras de origem humana. Além dos fatores já bem caracterizados e relacionados às ITU, como fímbrias do tipo1, $\mathrm{S}, \mathrm{P}$ e toxinas, tal abrangência possibilitou a identificação de genes relacionados a outras infecções extra-intestinais, como os genes ibeA e traT. Assim, a caracterização destas cepas de E. coli revelou o seu 
potencial patogênico, sugerindo que este patógeno poderia ocasionar outras enfermidades em cães e gatos, até mais severas que as ITU.

Neste estudo, os isolados de cães e gatos com ITU, quando comparados às amostras humanas, isoladas tanto de ITU como de meningite e outras infecções exta-intestinais, apresentam sorotipos em comum, compartilham o perfil de virulência, além de serem capazes de produzir $\alpha$-hemolisina e expressar as fímbrias do tipo 1 e/ou P. Estes dados reforçam a hipótese, defendida por muitos autores, de que tais clones encontram-se disseminados entre as espécies, possibilitando as infecções cruzadas, tanto de cães gatos para o homem, como do homem para estes animais. 


\section{Referenncias Bibliográficas"}

ALONSO, P.; BLANCO, J.; BLANCO, M.; GONZÁLEZ, E. A. Frequent production of toxins by Escherichia coli strains isolated from human urinary tract infections: relation with haemagglutination. FEMS Microbiol. Lett., 48:391-396, 1987.

ALONSO, M.P.; BLANCO, J.E.; GONZÁLEZ, E.A.; GARABAL, J.I. Characteristics of haemolytic Escherichia coli with particular reference to production of cytotoxic necrotizing factor type 1 (CNF 1). Res. Microbiol., 143:869-878, 1992.

BARSANTI J. A. Genitourinary infections. In: GREENE C. E. (Ed.). Infectious diseases of the dog and cat. $2^{\text {nd }}$ ed. Philadelfia: WB Sauders, 1998. p. 626-646.

BARTGES, J. W. Diagnosis of urinary tract infections. Vet. Clin. Small. Anim., v. 34, p. 923-933, 2004.

BAUER, R. J.; ZHANG, L.; FOXMAN, B.; SIITONEN, A.; JANTUNEN, M. E.; SAXEN, H.; MARRS, C. F. Molecular epidemiology of 3 putative virulence genes for Escherichia coli urinary tract infection-usp, iha, and iroN(E. coli). J. Infect. Dis., v. 185, p. 1521-1524, 2002.

BERGSTEN, G.; WULLT, B.; SVANBORG, C. Escherichia coli: fimbriae, bacterial persistence and host response induction in the human urinary tract. Int. J. Med. Microbiol., v. 295, p. 487-502, 2005.

BEUTIN, L.; MONTENEGRO, M.; ZIMMERMANN, S.; STEPHAN, R. Characterization of hemolytic strains of Escherichia coli belonging to classical enteropathogenic O-serogroups. Zentralbl. Bakteriol. Mikrobiol. Hyg. A, v. 261, p. 266-279, 1986.

BEUTIN, L: The different hemolysins of Escherichia coli. Med. Microbiol. Immunol. v. 180, p. $167-182,1991$.

"De acordo com:

ASSOCIAÇÃO BRASILEIRA DE NORMAS TÉCNICAS. NBR 6023: Informação e documentação: referências: elaboração. Rio de Janeiro, 2002. 
BIDET, P.; MAHJOUB-MESSAI, F.; BLANCO, J.; BLANCO, J.; DEHEM, M.; AUJARD, Y.; BINGEN, E.; BONACORSI, S. Combined multilocus sequence typing and $O$ serogrouping distinguishes Escherichia coli subtypes associated with infant urosepsis and/or meningitis. J. Infect. Dis., v. 196, p. 297-303, 2007.

BINGEN-BIDOIS, M.; CLERMONT, O.; BONACORSI, S.; TERKI, M.; BRAHIMI, N.; LOUKIL, C.; BARRAUD, D.; BINGEN, E. Phylogenetic analysis and prevalence of urosepsis strains of Escherichia coli bearing pathogenicity island-like domains. Infect. Immun., v. 70, p. 3216-3226, 2002.

BLANCO, J.; BLANCO, M.; ALONSO, M. P.; BLANCO, J. E.; GARABAL, J. I.; GONZALEZ, E. A. Serogroups of Escherichia coli strains producing cytotoxic necrotizing factors CNF1 and CNF2. FEMS Microbiol. Lett. 75: 155-159, 1992.

BLANCO, M.; BLANCO, J.E.; BLANCO, J.; ALONSO, M.P.; BALSALOBRE, C.; MOURIÑO, M.; MADRID, C.; JUÁREZ, A. Polymerase chain reaction for detection of Escherichia coli strains producing cytotoxic necrotizing factor type 1 and type 2 (CNF1 and CNF2). J. Microbiol. Methods, v. 26: p. 95-101, 1996.

BLANCO, L. J.; BARTGES, J. W. Understanding and eradicating bacterial urinary tract infections. Vet. Med., v.96, p. 777-789, 2001.

BLUMENTHAL, B.; HOFFMANN, C.; AKTORIES, K.; BACKERT, S.; SCHMIDT, G. The cytotoxic necrotizing factors from Yersinia pseudotuberculosis and from Escherichia coli bind to different cellular receptors but take the same route to the cytosol. Infect. Immun., v. 75, p. 3344-3353, 2007.

BONACORSI, S.; BINGEN, E. Molecular epidemiology of Escherichia coli causing neonatal meningitis. Int. J. Med. Microbiol., v. 295, p. 373-381, 2005.

BOWER, J. M.; ETO, D. S.; MULVEY, A. Covert operation of uropathogenic Escherichia coli wihin the urinary tract. Traffic, v. 6, p. 18-31, 2005.

BUSH, B. M. A review of the aetiology and consequences of urinary tract infections in the dog. Br. Vet. J., v. 132, p. 632-641, 1976.

CAPRIOLI, A.; FALBO, V.; RODA, L.G.; RUGGERI, F.M.; ZONA, C. Partial purification and characterization of an Escherichia coli toxic factor that induces morphological cell alteration. Infect. Immun., v. 39, p. 1300-1306,1983. 
CARBONETTI, N. H.; BOONCHAI, S.; PARRY, S. H.; VÄISÄNEN-RHEN, V.; KORHONEN, T. K.; WILLIAMS, P. H. Aerobactin-mediated iron uptake by Escherichia coli isolates from human extraintestinal infections. Infec. Immun., v. 51, p. 966-968, 1986.

CAVALIERI, S. J.; BOHACH, G. A.; SNYDER, I. S. Escherichia coli $\alpha$-hemolysin: characteristics and probable role in pathogenicity. Microbiol. Rev., v. 48, p. 326-343, 1984.

CETIN, C.; SENTÜRK, S.; KOCABIYIK, A. L.; TEMIZEL, M.; ÖZEL, E. Bacteriological examination of urine samples from dogs with symptoms of urinary tract infection. Turk. J. Vet. Anim. Sci., v. 27, p.1225-1229, 2003.

CHERIFI, A.; CONTREPOIS, M.; PICARD, B.; GOULLET, P.; ORSKOV, I.; ORSKOV, F.; DE RYCKE, J. Clonal relationships among Escherichia coli serogroup $\mathrm{O} 6$ isolates from human and animal infections. FEMS Microbiol. Lett., v. 64, p. 225230, 1991.

CLERMONT, O.; BONACORSI, S.; BINGEM, E. Rapid and simple determination of the Escherichia coli phylogenetic group. Appl. Environ. Microbiol., v. 66, p. 45554558, 2000.

CROSA, J. H. Genetics and molecular biology of siderophore-mediated iron transport in bacteria. Microbiol. Rev., v. 53, p. 517-530, 1989.

DE RYCKE, J.; NOUGAYREDE, J.P.; OSWALD, E.; MAZARS, P. Interaction of Escherichia coli producing cytotoxic necrotizing factor with HeLa epithelial cells. Adv. Exp. Med. Biol., v. 412, p. 363-366, 1997.

DE RYCKE, J.; MILON, A.; OSWALD, E. Necrotoxic Escherichia coli (NTEC): two emerging categories of human and animal pathogens. Vet. Res., v. 30, p. 221-233, 1999.

DOWLING, P. M. Antimicrobial therapy of urinary tract infections. Can. Vet. J., v. 37, p. 438-441, 1996.

DRAZENOVICH, N.; LING, G. V.; FOLEY, J. Molecular investigation of Escherichia coli strains associated with apparently persistent urinary tract infection in dogs. J. Vet. Intern. Med., v. 18, p. 301-306, 2004. 
DUGUID, J. P.; CLEGG, S.; WILSON, M.I. The fimbrial and non-fimbrial haemagglutinins of Escherichia coli. J. Med. Microbiol., v. 12, p. 213-227.

EVANS JR, D. J.; EVANS, D. G.; DUPONT, H. L. Hemagglutination patterns of enterotoxigenic and enteropathogenic Escherichia coli determined with human, bovine, chicken, and guinea pig erythrocytes in the presence and absence of mannose. Infect. Immun., v. 23, p. 336-346, 1979.

EWERS, C.; LI, G.; WILKING, H.; KIESSLING, S.; ALT, K.; ANTÁO, E. M.; LATURNUS, C.; DIEHL, I.; GLODDE, S.; HOMEIER, T.; BÖHNKE, U.; STEINRÜCK, H.; PHILIPP, H. C.; WIELER, L. H. Avian pathogenic, uropathogenic, and newborn meningitis-causing Escherichia coli: how closely related are they? Int. J. Med. Microbiol., v. 297, p. 163-176, 2007.

FALBO, V.; FAMIGLIETTI, M.; CAPRIOLI, A. Gene block encoding production of cytotoxic necrotizing factor 1 and hemolysin in Escherichia coli isolates from extraintestinal infections. Infect. Immun., v. 60, p. 2182-2187, 1992.

FEIN, J. E. Screening of uropathogenic Escherichia coli for expression of mannoseselective adhesins: importance of culture conditions. J. Clin. Microbiol., v. 13, p. 1088-1095, 1981.

FERNANDEZ-BEROS, M. E.; KISSEL, V.; LIOR, H.; CABELLO, F. C. Virulencerelated genes in CoIV plasmids of Escherichia coli isolated from human blood and intestines. J. Clin. Microbiol., v.28, p. 742-746, 1990.

FREITAG, T.; SQUIRES, R. A.; SCHMID, J.; ELLIOTT, J. Feline uropathogenic Escherichia coli from Great Britain and New Zealand have dissimilar virulence factor genotypes. Vet. Microbiol., v. 106, p. 79-86, 2005.

GILSON, L.; MAHANTY, H. K.; KOLTER, R. Four plasmid genes are required for colicin V synthesis, export, and immunity. J. Bacteriol., v.169, p. 2466-2470, 1987.

GREENE, C. E. Infectious diseases of the dog and cat. $3^{\text {rd }}$ ed. London: Saunders Elsevier; 2006.

GRINDLAY, M.; RENTON, J. P.; RAMSAY, D. H. O-groups of E. coli associated with canine pyometra. Res. Vet. Sci., v. 14, p. 75-77, 1973. 
GYLES, C. L.; FAIRBROTHER, J. M. Escherichia coli. In: GYLES, C. L.; PRESCOTT, J. F.; SONGER, J. G.; THOEN, C. O. Pathogenesis of bacterial infections in animals. Massachusetts: Blackwell Publishing, 2004. p. 193-194.

HACKER, J. Role of fimbrial adhesins in pathogenesis of Escherichia coli infections. Can. J. Microbiol., v. 38, p. 720-727, 1992.

HACKER, J.; BLUM-OEHLER, G.; MÜHLDORFER, I.; TSCHÄPE, H. Pathogenicity islands of virulent bacteria: structure, function and impact on microbial evolution. Mol. Microbiol., v. 23, p. 1089-1097, 1997.

HACKER, J.; BLUM-OEHLER, G. In appreciation of Theodor Escherich. Nat. Rev. Microbiol., v. 5, p. 902, 2007.

HAGAN, E. C.; MOBLEY, H. L. T. Uropathogenic Escherichia coli outer membrane antigens expressed during urinary tract infection. Infect. Immun., v. 75, p. 3941-49, 2007.

HAGBERG, L.; JODAL, U.; KORHONEN, T. K.; LINDIN-JANSON, G.; LINDBERG, U.; EDÉN, C. S. Adhesion, hemagglutination, and virulence Escherichia coli causing urinary tract infections. Infect. Immun., v. 31, p. 564-570, 1981.

HANCOCK, V.; FERRIÈRES, L.; KLEMM, P. The ferric yersiniabactin uptake receptor FyuA is required for efficient biofilm formation by urinary tract infectious Escherichia coli in human urine. Microbiology, v. 154, p. 167-175, 2008.

HERRERO, M.; LORENZO, V.; NEILANDS, J. B. Nucleotide sequence of the iucD gene of the pColV-K30 aerobactin operon and topology of its product studied with phoA and lacZ gene fusions. J. Bacteriol., v. 170, p. 56-64, 1988.

HOLDEN, N. J.; TOTSIKA, M.; MAHLER, E.; ROE, A. J.; CATHERWOOD, K.; LINDNER, K.; DOBRINDT, U.; GALLY, D. L. Demonstration of regulatory cross-talk between $\mathrm{P}$ fimbriae and type 1 fimbriae in uropathogenic Escherichia coli. Microbiology, v. 152, p. 1143-1153, 2006.

HUANG, S. H.; WASS, C.; FU, Q.; PRASADARAO, N. V.; STINS, M.; KIM, K. S. Escherichia coli invasion of brain microvascular endothelial cells in vitro and in vivo: molecular cloning and characterization of invasion gene ibe10. Infect. Immun., v. 63, p. 4470-4475, 1995. 
JOHNSON, J. R.; MOSELEY, S. L.; ROBERTS, P. L.; STAMM, W. E. Aerobactin and other virulence factor genes among strains of Escherichia coli causing urosepsis: association with patient characteristics. Infect. Immun., v. 56, p. 405-412, 1988.

JOHNSON, J. R. Virulence factors in Escherichia coli urinary tract infections. Clin. Microbiol. Rev., v. 4, p. 80-128, 1991.

JOHNSON, J. R.; STELL, A. L. Extend virulence genotypes of Escherichia coli strains from patients with urosepsis in relation to pylogeny and host compromise. J. Infect. Dis., v. 181, p. 261-72, 2000.

JOHNSON, J. R.; RUSSO, T. A.; TARR, P. I.; CARLINO, U.; BILGE, S. S.; VARY, J. C.; STELL, A. L. Molecular epidemiological and phylogenetic associations of two novel putative virulence genes, iha and iro $N_{E . c o l i}$, among Escherichia coli isolates from patients with urosepsis. Infect. Immun., v. 68, p. 3040-3047, 2000.

JOHNSON, J. R.; DELAVARI, P.; STELL, A. L.; WHITTAM, T. S.; CARLINO, U.; RUSSO, T. A. Molecular comparison of extraintestinal Escherichia coli isolates of the same electrophoretic lineages from humans and domestic animals. J. Infect. Dis., v. 183, p. 154-159, 2001 a.

JOHNSON, J. R.; DELAVARI, P.; O'BRYAN, T. T. Escherichia coli O18:K1:H7 isolates from patients with acute cystitis and neonatal meningitis exhibit common phylogenetic origins and virulence factor profiles. J. Infect. Dis., v. 183, p. 425-434, 2001b.

JOHNSON, J. R.; RUSSO, T. A. Extraintestinal pathogenic Escherichia coli: "The other bad E. coll'. J. Lab. Clin. Med., v. 139, p. 155-162, 2002.

JOHNSON, J. R.; KASTER, N.; KUSKOWSKI, M. A.; LING, G. V. Identification of urovirulence traits in Escherichia coli by comparison of urinary and rectal $E$. coli isolates from dogs with urinary tract infection. J. Clin. Microbiol., v. 41, p. 337-345, 2003.

JOHNSON, J. R.; RUSSO, T. A. Molecular epidemiology of extraintestinal pathogenic (uropathogenic) Escherichia coli. Int. J. Med. Microbiol., v. 259, p. 383-404, 2005.

JOHNSON, J. R.; KUSKOWSKI, M. A.; GAJEWSKI, A.; SOTO, S.; HORCAJADA, J. P.; JIMENEZ DE ANTA, M. T.; VILA, J. Extended virulence genotypes and phylogenetic background of Escherichia coli isolates from patients with cystitis, pyelonephritis, or prostatitis. J. Infect. Dis., v. 191, p. 46-50, 2005. 
JOHNSON, J. R.; OWENS, K. L.; CLABOTS, C. R.; WEISSMAN, S. J.; CANNON, S. $B$. Phylogenetic relationships among clonal groups of extraintestinal pathogenic Escherichia coli as assessed by multi-locus sequence analysis. Microbes Infect., v. 8, p. 1702-1713, 2006.

JOHNSON, J. R.; JOHNSTON, B.; CLABOTS, C. R.; KUSKOWSKI, M. A.; ROBERTS, E.; DEBROY, C. Virulence genotypes and phylogenetic background of Escherichia coli serogroup 06 isolates from humans, dogs, and cats. J. Clin. Microbiol., v. 46, p. 417-422, 2008.

KAO, J. S.; STUCKER, D. M.; WARREN, J. W.; MOBLEY, H. L. T. Pathogenicity island sequences of pyelonephritogenic Escherichia coli CFT073 are associated with virulent uropathogenic strains. Infect. Immun., v. 65, p. 2812-2820, 1997.

KAPER, J. B.; NATARO, J. P.; MOBLEY, H. L. T. Pathogenic Escherichia coli. Nat. Rev. Microbiol., v. 2, p. 123-140, 2004.

KOCZURA, R; KAZNOWSKI, A. The Yersinia high-pathogenicity island and ironuptake systems in clinical isolates of Escherichia coli. J. Med. Microbiol., v. 52, p. 637-642, 2003.

KONEMAN, E. W.; ALLEN, S. D.; JANDA, W. M.; SCHRECKENBERGER, P. C.; WINN Jr, W. C. Color atlas and textbook of diagnostic microbiology. $5^{\text {th }}$ ed. Philadelphia: Lippincott, 1997. p. 1395.

KUCHERIA, R.; DASGUPTA, P.; SACKS, S. H.; KHAN, M.S.; SHEERIN, N. S. Urinary tract infections: new insights into a common problem. Postgrad. Med. J., v. 81, p. 83-86, 2005.

KURAZONO, H.; NAKANO, M.; YAMAMOTO, S.; OGAWA, O.; YURI, K.; NAKATA, K.; KIMURA, M.; MAKINO, S., NAIR, G. B. Distribution of the usp gene in uropathogenic Escherichia coli isolated from companion animals and correlation with serotypes and size-variations of the pathogenicity island. Microbiol. Immunol., v. 47, p. 797-802, 2003.

LABIGNE-ROUSSEL, A. F.; LARK, D.; SCHOOLNIK, G.; FALKOW, S. Cloning and expression of an afimbrial adhesin (AFA-I) responsible for $P$ blood groupindependent, mannose-resistant hemagglutination from a pyelonephritic Escherichia coli strain. Infect. Immun., v. 46, p. 251-259, 1984. 
LE BOUGUENEC, C.; ARCHAMBAUD, M.; LABIGNE, A. Rapid and Specific Detection of the pap, afa, and sfa adhesin-encoding operons in uropathogenic Escherichia coli strains by polymerase chain reaction. J. Clin. Microbiol., v. 30, p. 1189-1193, 1992.

LE BOUGUÉNEC, C.; BERTIN, Y. AFA and F17 adhesins produced by pathogenic Escherichia coli strains in domestic animals. Vet. Res., v. 30, p. 317-342,1999.

LE BOUGUÉNEC, C.; LALIOUI, L.; MERLE, L.; JOUVE, M.; COURCOUX, P.; BOUZARI, S.; SELVARANGAN, R.; NOWICKI, B.; GERMANI, Y.; ANDREMONT, A.; GOUNON, P.; GARCIA, M. I. Characterization of AfaE adhesins produced by extraintestinal and intestinal human Escherichia coli isolates: PCR assays for detection of Afa adhesins that do or do not recognize Dr blood group antigens. J. Clin. Microbiol., v. 39, p. 1738-1745, 2001.

LE BOUGUÉNEC, C. Adhesins and invasins of pathogenic Escherichia coli. Int. J. Med. Microbiol., v. 295, p. 471-478, 2005.

LEES, G. E. Bacterial urinary tract infections. Vet. Clin. North Am. Small Anim. Pract., v. 26, p. 297-304, 1996.

LE GALL, T.; CLERMONT, O.; GOURIOU, S.; PICARD, B.; NASSIF, X.; DENAMUR, E.; TENAILLON, O. Extraintestinal virulence is a coincidental by-product of commensalism in B2 phylogenetic group Escherichia coli strains. Mol. Biol. Evol., v. 24, p. 2373-2384, 2007.

LÉVEILLÉ, S.; CAZA, M.; JOHNSON, J. R.; CLABOTS, C.; SABRI, M.; DOZOIS, C. $M$. Iha from an Escherichia coli urinary tract infection outbreak clonal group $A$ strain is expressed in vivo in the mouse urinary tract and functions as a catecholate siderophore receptor. Infect. Immun., v. 74, n. 6, p. 3427-3436, 2006.

LING, G. V.; NORRIS, C. R.; FRANTI, C. E.; EISELE, P. H.; JOHNSON, D. L.; RUBY, A. L.; JANG, S. S. Interrelations of organism prevalence, specimen collection method, and host age, sex, and breed among 8,354 canine urinary tract infections (1969-1995). J. Vet. Intern. Med., v. 15, p. 341-347, 2001.

LOW, D. A.; BRAATEN, B. A.; LING, G. V.; JOHNSON, D. L.; RUBY, A. L. Isolation and comparison of Escherichia coli strains from canine and human patients with urinary tract infections. Infect. Immun., v. 56, p. 2601-2609, 1988.

LULICH, J. P.; OSBORNE, C. A. Urine culture as a test for cure: why, when, and how? Vet. Clin. Small Anim., v. 34, p. 1027-1041, 2004. 
MARTINEZ, J. J.; MULVEY, M. A.; SCHILLING, J. D.; PINKER, J. S.; HULTGREN, S. J. Type 1 pilus-mediated bacterial invasion of bladder epithelial cells. EMBO J., v. 19 , p. 2803-2812, 2000.

MCNICHOL, B. A.; RASMUSSEN, S. B.; CARVALHO, H. M.; MEYSICK, K. C.; O'BRIEN, A. D. Two domains of cytotoxic necrotizing factor type 1 bind the cellular receptor, laminin receptor precursor protein. Infect. Immun., v. 75, p. 5095-5104, 2007.

MEYER, D. J.; COLES, E. H.; RICH, L. J. Medicina de laboratório veterinária. Diagnóstico e interpretação. São Paulo: Roca, 1995. 308 p.

MIYAZAKI, J.; BA-THEIN, W.; KUMAO, T.; YASUOKA, M. O.; AKAZA, H.; HAYSHI, $H$. Type 1, $P$ and $S$ fimbriae and afimbrial adhesin are not essencial for uropathogenic $E$. coli to adhere to and invade bladder epithelial cells. FEMS Immunol. Med. Microbiol., v. 33, p. 23-26, 2002.

MOBLEY, H. L.; GREEN, D. M.; TRIFILLIS, A. L.; JOHNSON, D. E.; CHIPPENDALE, G. R.; LOCKATELL, C. V.; JONES, B. D.; WARREN, J. W. Pyelonephritogenic Escherichia coli and killing of cultured human renal proximal tubular epithelial cells: role of hemolysin in some strains. Infect. Immun., v. 58, p. 1281-1289, 1990.

MULVEY, M. A.; SCHILLING, J. D.; MARTINEZ, J. J.; HULTGREN, S. J. Bad bugs and beleaguered bladders: Interplay between uropathogenic Escherichia coli and innate host defenses. Proc. Natl. Acad. Sci. U.S.A., v. 97, p. 8829-8835, 2000.

MÜHLDORFER, I.; HACKER, J. Genetic aspects of Escherichia coli virulence. Microb. Pathog., v. 16, p. 171-181.

MURRAY, A. C.; KUSKOWSKI, M. A.; JOHNSON, J. R. Virulence factors predict Escherichia coli colonization patterns among human and animal household members. Ann. Intern. Med., v. 140, p. 848-849, 2004.

NORRIS, C. R.; WILLIAMS, B. J.; LING, G. V.; FRANTI, C. E., JOHNSON, D. L.; RUBY, A. L. Recurrent and persistent urinary tract infections in dogs: 383 cases (1969-1995). J. Am. Anim. Hosp. Assoc., v. 36, p. 484-492, 2000.

OELSCHLAEGER, T. A.; DOBRINDT, U.; HACKER, J. Pathogenicity islands of uropahtogenic $E$. coli and the evolution of virulence. Int. J. Antimicrob. Agents, v. 19, p. 517-521, 2002. 
ORSKOV, I.; ORSKOV, F. Escherichia coli in extra-intestinal infections. J. Hyg., v. 95, p. 551-575, 1985.

OTT, M.; HACKER, J.; SCHMOLL, T.; JARCHAU, T.; KORHONEN, T.K.; GOEBEL, W. Analysis of the genetic determinants coding for the S-Frimbrial adhesin (sfa) in different Escherichia coli strains causing meningitis or urinary tract infections. Infect. Immun., v. 54, p. 646-653, 1986.

PICARD, B.; GARCIA, J. S.; GOURIOU, S.; DURIEZ, P.; BRAHIMI, N.; BINGEN, E.; ELION, J.; DENAMUR, E. The link between phylogeny and virulence in Escherichia coli extraintestinal infection. Infect. Immun., v. 67, p. 546-553, 1999.

POLZIN, D. J. Management of recurrent bacterial urinary tract infections. Cycle Symp., v. 16, p. 1565-1570, 1994.

PRAMOONJAGO, P.; KANEKO, M.; KINOSHITA, T.; OHTSUBO, E.; TAKEDA, J.; HONG, K.; INAGI, R.; INOUE, K. Role of TraT protein, an anticomplementary protein produced in Escherichia coli by R100 factor, in serum resistance. J. Immunol., v. 148, p. 827-836, 1992.

REEVES, P. R.; HOBBS, M.; VALVANO, M. A.; SKURNIK, M.; WHITFIELD, C.; COPLIN, D.; KIDO, N.; KLENA, J.; MASKELL, D.; RAETZ, C. R. H.; RICK, P. D. Bacterial polysaccharide synthesis and gene nomenclature. Trend Microbiol., v. 4, p. 495-503, 1996.

ROOS, V.; NIELSEN, E. M.; KLEMM, P. Asymptomatic bacteriuria Escherichia coli strains: adhesins, growth and competition. FEMS Microbiol. Lett., v. 262, p. 22-30, 2006.

RUSSO, T. A.; JOHNSON, J. R. Proposal for a new inclusive designation for extraintestinal pathogenic isolates of Escherichia coli. J. Infect. Dis., v. 181, p. 17531754, 2000.

SAMUEL, G.; REEVES, P. R. Biosynthesis of O-antigens: genes and pathways involved in nucleotide sugar precursor synthesis and O-antigen assembly. Carbohydr. Res., v. 338, p. 2503-2519, 2003.

SALYERS, A. A.; WHITT, D. D. Bacterial pathogenesis: a molecular approach. $2^{\text {nd }}$ ed. Washington: ASM Press, 2002. p. 539. 
SEGUIN, M. A.; VADEN, S. L.; ALTIER, C.; STONE, E.; LEVINE, J. F. Persistent urinary tract infections and reinfections in 100 dogs (1989-1999). J. Intern. Med., v. 17, p. 622-631, 2003.

SCHILLING, J. D.; MULVEY, M. A.; HULTGREN, S. J. Structure and function of Escherichia coli type 1 pili: new insight into the pathogenesis of urinary tract infections. J. Infect. Dis., v. 183, p. S36-40, 2001.

SCHMIDT, H.; HENSEL, M. Pathogenicity islands in bacterial pathogenesis. Clin. Microbiol. Rev., v. 17, p. 14-56, 2004.

SCHUBERT, S; RAKIN, A.; KARCH, H.; CARNIEL, E.; HEESEMANN, J. Prevalence of the "high-pathogenicity island" of Yersinia species among Escherichia coli strains that are pathogenic to humans. Infect. Immun., v. 6, p. 480-485, 1998.

SMITH, J. L.; FRATAMICO, P. M.; GUNTHER, N. W. Extraintestinal pathogenic Escherichia coli. Foodborne Pathog. Dis., v. 4, p. 134-163, 2007.

SNYDER, J. A.; HAUGEN, B. J.; BUCKLES, E. L.; LOCKATELL, C. V.; JOHNSON, D. E.; DONNENBERG, M. S., WELCH, R. A.; MOBLEY, H. L. T. Transcriptome of uropathogenic Escherichia coli during urinary tract infection. Infect. Immun., v. 72, p. 6373-6381, 2004.

SOKURENKO, E. V.; COURTNEY, H. S.; OHMAN, D. E.; KLEMM, P.; HASTY, D. L. FimH family of type 1 fimbrial adhesins: functional heterogeneity due to minor sequence variations among fimH genes. J. Bacteriol., v. 146, p. 748-755, 1994.

STENUTZ, R.; WEINTRAUB, A.; WILDMALM, G. The structures of Escherichia coli O-polysaccharide antigens. FEMS Microbiol. Rev., v. 30, p. 382-403, 2006.

SUKUPOLVI, S.; O'CONNOR, C. D. TraT lipoprotein, a plasmid-specified mediator of interactions between gram-negative bacteria and their environment. Microbiol. Rev., v.54, p. 334-341, 1990.

TARR, P. I.; BILGE, S. S.; VARY Jr, J. C.; JELACIC, S.; HABEEB, R. L.; WARD, T. R.; BAYLOR, M. R.; BESSER, T. E. Iha: a novel Escherichia coli O157:H7 adherence-conferring molecule encoded on a recently acquired chromosomal island of conserved structure. Infect. Immun., v. 68, p. 1400-1407, 2000. 
TROEGER, H.; RICHRWE, J. F.; BEUTIN, L.; GÜNZEL, D.; DOBRINDT, U.; EPPLE, H. J.; GITTER, A. H.; ZEITZ, M.; FROMM, M.; SCHULZKE, J. D. Escherichia coli alpha-haemolysin induces focal leaks in colonic eputhelium: a novel mechanism of bacterial translocation. Cell Microbiol., v. 9, p. 2530-2540, 2007.

WELCH, R. A.; BURLAND, V.; PLUNKETT III, G.; REDFORD, P.; ROESCH, P.; RASKO, D.; BUCKLES, E. L.; LIOU, S. R.; BOUTIN, A.; HACKETT, J.; STROUD, D.; MAYHEW, G. F.; ROSE, D. J.; ZHOU, S.; SCHWAERTZ, D. C.; PERNA, N. T.; MOBLEY, H. L. T.; DONNENBERG, M. S.; BLATTNER, F. R. Extensive mosaic structure revealed by the complete genome sequence of uropathogenic Escherichia coli. Proc. Nat. Acad. Sci. USA, v. 99, p. 17020-17024, 2002.

WESTERLUNG, B.; PERE, A.; KORHONEN, T. K.; JARVINEN, A. K.; WILLIAMS, P. $\mathrm{H}$. Characterization of $E$. coli strains associated with canine urinary tract infections. Res. Vet. Sci., v. 42, p. 404-406, 1987.

WILES, T. J.; KULESUS, R. R.; MULVEY, M. A. Origins and virulence mechanisms of uropathogenic Escherichia coli. Exp. Mol. Pathol., v. 85, p. 11-19, 2008.

WILKINSON, G. T. O-groups of E. coli in the vagina and alimentary tract of the dog. Vet. Rec., v. 94, p. 105, 1974.

WILSON, R. A.; KEEFE, T. J.; DAVIS, M. A.; BROWNING, M. T.; ONDRUSEK, K. Strains of $E$. coli associated with urogenital disease in dogs and cats. Am. J. Vet. Res., v. 49, p. 743-754, 1988.

WHITFIELD, C. Biosynthesis of lipopolysaccharide $\mathrm{O}$ antigens. Trends Microbiol., v. 3, p. 178-185, 1995.

WOOLEY, R. E.; BLUE, J. L. Quantitative and bacteriological studies from canine and feline urinary tract infections. J. Clin. Microbiol., v. 4, p. 326-329, 1976.

WU, X. R.; SUN, T. T.; MEDINA, J.J. In vitro binding of type 1-fimbriated Escherichia coli to uroplakins la and Ib: relation to urinary tract infections. Proc. Natl. Acad. Sci. U.S.A., v. 93, p. 9630-9635, 1996.

XIA, Y.; FORSMAN-SEMB, K.; JASS, J.; UHLIN, B. E. Structural and functional studies of the fimbrial adhesin gene regulator PapB from uropathogenic Escherichia coli. Adv. Exp. Med. Biol., v. 485, p. 123-126, 2000. 
XIE, Y.; KIM, K. J.; KIM, K. S. Current concepts on Escherichia coli K1 translocation of the blood-brain barrier. FEMS Immunol. Med. Microbiol., v. 42, p. 271-279, 2004.

YAMAMOTO, S.; TSUKAMOTO, T.; TERAI, A.; KURAZONO, H.; TAKEDA, Y.; YOSHIDA, O. Distribution of virulence factors in Escherichia coli isolated from urine of cystitis patients. Microbiol. Immunol., v. 39, p. 401-404, 1995.

YURI, K.; NAKATA, K.; KATAE, H.; YAMAMOTO, S.; HASEGAWA, A. Distribution of uropathogenic factors among Escherichia coli strains isolated from dogs and cats. J. Vet. Med. Sci., v. 60, p. 287-290, 1998 a.

YURI, K.; NAKATA, K.; KATAE, H.; TSUKAMOTO, T.; HASEGAWA, A. Serotypes and virulence factors of Escherichia coli strains isolated from dogs and cats. J. Vet. Med. Sci., v. 61, p. 37-40, 1998b.

YURI, K.; NAKATA, K.; KATAE, H.; HASEGAWA, A. Pathogenicity of Escherichia coli from dogs with UTI in relation to urovirulence factors. J. Vet. Med. Sci., v. 62, p. 1197-1200, 2000. 